\title{
Investigated Cold Press Oil Extraction from Non-Edible Oilseeds for Future Bio-Jet Fuels Production
}

\author{
Xianhui Zhao, Lin Wei*, James Julson, Yinbin Huang \\ Department of Agricultural and Biosystems Engineering, South Dakota State University, Brookings, USA \\ Email: ${ }^{\text {lin.wei@sdstate.edu }}$
}

Received 7 September 2014; revised 18 October 2014; accepted 6 November 2014

Copyright () 2014 by authors and Scientific Research Publishing Inc.

This work is licensed under the Creative Commons Attribution International License (CC BY). http://creativecommons.org/licenses/by/4.0/

(c) (i) Open Access

\begin{abstract}
Bio-jet fuel produced from non-edible oilseeds can be an alternative to fossil fuels with the benefits of increasing national energy security, reducing environmental impact, and fostering rural economic growth. Efficient oil extraction from oilseeds is critical for economic production of bio-jet fuels. Oil extractions from camelina (sativa) and canola (Brassica napus) seeds were conducted using a cold press method. The effect of the frequency controlling the screw rotation speed on the oil recovery and quality was discussed. Characterization of the produced raw vegetable oils, such as heating value, elemental content and main chemical compositions, was carried out. The results showed that the oil recovery increased when the frequency decreased. The highest oil recoveries for camelina and canola seeds were $88.2 \%$ and $84.1 \%$ respectively, both at $15 \mathrm{~Hz}$. The cold press frequency and processing temperature $\left(97.2^{\circ} \mathrm{C}-106.0^{\circ} \mathrm{C}\right)$ had a minor influence on the qualities and recovery of both camelina and canola oils. In addition, camelina and canola oils produced at $15 \mathrm{~Hz}$ underwent catalytic cracking to examine potential hydrocarbon fuels production. It was observed that some of oil physicochemical properties were improved after catalytic cracking. Although more study is needed for further improvement of oil recovery and qualities, cold press could be an efficient method for oil extraction from non-edible oilseeds. Additionally, the preliminary results of upgrading the oils produced show very promising for future bio-jet fuels production.
\end{abstract}

\section{Keywords}

Camelina, Canola, Cold Press, Oil Recovery, Upgrading

\footnotetext{
${ }^{*}$ Corresponding author.
}

How to cite this paper: Zhao, X.H., Wei, L., Julson, J. and Huang, Y.B. (2014) Investigated Cold Press Oil Extraction from Non-Edible Oilseeds for Future Bio-Jet Fuels Production. Journal of Sustainable Bioenergy Systems, 4, 199-214. 


\section{Introduction}

As a result of concerning food vs. fuel debates, current biofuel development has focused on non-edible feedstock sources. Presently, a large number of non-edible vegetable oils are available, which do not compete with the food industry, so they can provide a source for bio-jet fuel production. In general, non-edible vegetable oil sources are classified into three categories: non-edible plant oils (e.g. Camelina sativa, Jatropha curcas, Nicotiana tabacum and tamanu), recycled oils derived from edible oilseed processing waste, and waste cooking oils. For example, genetically modified canola grown on margin lands has been identified as a sustainable biofuel source because it doesn't occupy arable land. These margin lands are largely unproductive, or located in degraded forests and poverty-stricken areas. However, the canola plants are well adapted to arid and semi-arid conditions as they can grow on lands with low fertility and moisture, such as fallow lands, cultivators' field boundaries and old mining lands [1] [2]. Canola seeds contain about $40 \%$ oil and they are marketed worldwide [3]. Another non-edible vegetable oil producer is Camelina sativa seed, which is a non-edible oilseed that can be grown on marginal lands with a low input cost. One advantage of this oilseed is its resistance to blackleg, a disease that infects sunflowers, safflowers and many other crops. In Montana State of the United States, camelina is expected to have seed yield of 1800 to 2000 pounds per acre under dry land conditions [4]. Due to the widespread production, the camelina and canola seeds are considered important renewable energy sources.

Oilseeds produce oils that may be subsequently upgraded into saturated, unbranched and long-chain hydrocarbon fuels, which are suitable for bio-jet fuel production [5]. Using vegetable oils for bio-jet fuel production has potential advantages, such as high energy density, low moisture content and high-relative stability [6] [7]. Converting vegetable oils to bio-jet fuels includes three main steps. First, oil is extracted from vegetable oilseeds. Next, oil is upgraded into hydrocarbon fuel. Finally, hydrocarbon fuel is delivered to petroleum refinery for production of bio-jet fuel.

Vegetable oil extraction from oilseeds is a key step for bio-jet fuel production. Vegetable oil properties, specifically fatty acid profiles (FAPs) of oils, are dependent on oilseed species, oil extraction techniques and processing conditions. FAP is the quantitative composition of fatty acids in a vegetable oil. $\mathrm{C}_{16}$ and $\mathrm{C}_{18}$ fatty acids are the most common fatty acids in the vegetable oil. Fatty acids could affect the characteristics of vegetable oil, such as viscosity, oxidative stability, boiling point and combustion energy, so vegetable oil with good FAP is easily upgraded into a desired hydrocarbon fuel at high efficiency and low cost [8] [9]. Conventional methods of vegetable oil extraction include distillation, maceration, solvent extraction and cold press. The concentration of fatty acids in oil extracted from seeds using cold press method is similar to that using solvent extraction with petroleum-ether method, supercritical fluid extraction method and aqueous extraction method [2]. Each method has its own advantages and disadvantages. Using distillation technology consumes high energy and has slow output. The process of maceration is quite time-consuming. Solvent extraction is an expensive method with foam deposits in distillation. However, cold press has low capital cost with minimal labor. It is used in a small scale, which is suitable for oil extraction in rural areas. Also, it involves no organic solvent, and thus the product is chemically contaminant free. Additionally, the byproduct of vegetable oilseed meal has many potential applications. For example, the crude canola meal has been explored for use in dairy, poultry, floor covering, paper coatings, insulation and bio-composites [10]-[12]. Furthermore, recycling oilseed meals can increase oil extraction plant revenues, which could improve the economic viability of bio-jet fuel production [13].

Rombaut et al. have used screw pressing method to extract oils from grape seeds. They found that screw pressing was an efficient process for extracting grape seed oils with a high oil recovery [14]. Yetim et al. determined the fatty acid compositions of oils cold pressed from seven plant seeds in Turkey [10]. Biswas et al. used a catalytic cracking method to upgrade soybean oil. They found only liquid product with total absence of non-condensable gases when using a complex catalyst of $\mathrm{Zr}-\mathrm{Zr}$ covalently bonded with alumina. Also, increasing reaction temperature could increase the alkane content with fewer fatty acids [15]. However, there are few related papers or reports about vegetable oil used as bio-jet fuel from purely experimental fuels to commercialization.

The goal of this study is to explore a sustainable pathway to produce bio-jet fuel from non-edible vegetable seeds. In the present work, oil extraction from non-edible camelina and canola seeds will be performed using the cold press method. The vegetable oils produced will be characterized. The effects of screw rotation speed frequency on the oil recovery and properties, such as moisture content, $\mathrm{pH}$ value, density, dynamic viscosity, elemental content and chemical composition will be discussed. In addition, a preliminary catalytic cracking test of camelina and canola oils produced at $15 \mathrm{~Hz}$ will be conducted to examine their potential for upgrading to hydrocarbon fuels. 


\section{Materials and Methods}

\subsection{Material and Device Preparation}

Camelina (sativa) seeds were purchased from Hancock Seed Company, Dade, Florida, USA. Canola (Brassica napus) seeds were purchased from Agriculture and Agri-Food Canada, Ottawa, Ontario, Canada. These oilseeds, shown in Figure 1, were packed in bags and delivered to our biofuel laboratory. The bags were sealed and stored in the biofuel laboratory at room temperature for about four months before oil extraction started. There was no rancid smell or spoiling oilseed found during the oil extraction trials. These oilseeds had good quality prior to the tests. Both oilseed varieties were used directly without further treatment in this study. The M70 Oil Press was purchased from Oil Press Company, Eau Claire, Wisconsin, USA. It can produce about 70 gallons of oils from vegetable seeds and nuts each day running 24 hours. Table 1 lists the particle size, shape, bulk density and moisture content of camelina and canola seeds. The camelina seeds were quite small and had a rough surface. The length and width of seeds were measured based on the standard of ASTM D 4791. The size of seeds was tested using a proportional caliper device. The length means the maximum dimension of particles and the width refers to the maximum dimension in the plane perpendicular to the length. The moisture contents of seeds were determined by following the ASABE standards. The sample was dried in an oven at $105^{\circ} \mathrm{C}$ for 24 hours. Afterward, the dried sample was weighed to calculate the water content in the seeds [16]. Bulk density is an important physical characteristic of oilseeds that may affect the cold press processing. It is determined by following the ASABE standards. A cylindrical container with an inside diameter was used to measure the bulk density. The oilseed sample was poured into the container from a certain height to help with the free flow of particles. When the container was overfilled, a straight edge was stricken across the top of the container to remove the excess particles. Each measurement was repeated one time. The weight of the sample was measured. The height and inside diameter of the container was used to calculate its volume. Then, the bulk density was calculated by dividing the weight of sample over the volume of the container [17]. As shown in Table 1, camelina seeds had a slightly higher bulk density than canola seeds. The moisture of camelina seeds was less than that of canola seeds.

\subsection{Experimental Procedure}

Oil extraction from camelina and canola seeds was carried out at different frequencies using the M70 Oil Press

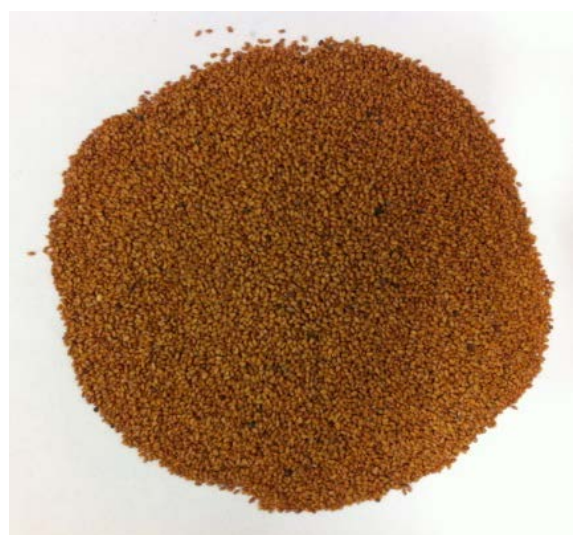

(a)

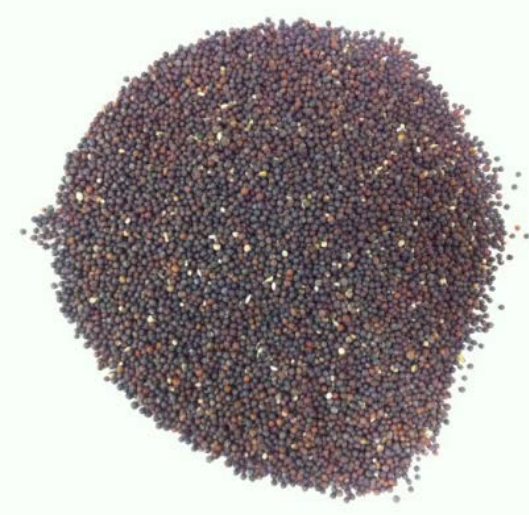

(b)

Figure 1. Oilseeds: (a) camelina (sativa) seeds; (b) canola (napus) seeds.

Table 1. The physical properties of flax and canola seeds.

\begin{tabular}{|c|c|c|c|c|c|}
\hline Oilseeds & Length (mm) & Width (mm) & Shape & Bulk Density (g/mL) & Moisture (wt $\%$ ) \\
\hline Camelina & $1.6-1.9$ & $0.7-1.0$ & Oval & $0.76 \pm 0$ & $4.92 \pm 0.04$ \\
\hline Canola & $1.1-1.8$ & $1.1-1.8$ & Tiny round & $0.72 \pm 0.02$ & $5.36 \pm 0.04$ \\
\hline
\end{tabular}


to discover the highest recovery of vegetable oils. The M70 Oil Press, as shown in Figure 2, mainly consists of a nozzle, a heat bond, meshes, a feeder, a motor, a frequency switch and a screw. The screw press is consisted of a horizontal screw and a vertical feeder. The Oil Press was operated to extract oils from vegetable oilseeds. The press barrel was preheated to $100^{\circ} \mathrm{C}$, which was helpful for the oil extrusion. Before oilseeds were fed in through the vertical feeder, the screw was started at a setting frequency that was controlled by the Variable Frequency Drive (VFD) in order to avoid the blockage of oilseeds. Oilseeds were compressed and milled by the screw. Oils would be extruded out of the oilseeds and collected from small meshes below the screw. Friction created during the screw rotation provided heat for the oils and improved oil flow. Meanwhile, meals were removed through the nozzle in front of the screw. Based on the results of preliminary test runs, the Oil Press machine might not be able to work properly when the electrical frequency is greater than $25 \mathrm{~Hz}$ or less than $15 \mathrm{~Hz}$. Therefore, the oilseeds were cold pressed at $15 \mathrm{~Hz}, 20 \mathrm{~Hz}$, and $25 \mathrm{~Hz}$ respectively. The test runs were duplicated. Totally, twelve test runs were needed for the study.

After screw pressing the oilseeds, some oils remained in the meals. The meals were then ground using a mill (Thomas-Wiley Laboratory Mill, Model 4, Thomas Scientific, USA) and sieved through a 10 mesh screen. The meal flours were processed using a solvent extraction method to determine the residual oil content. An Accelerated Solvent Extractor (Dionex ASE 350, Thermo Scientific Company) was utilized to test the residual oil content in meals.

Camelina and canola oils cold pressed at $15 \mathrm{~Hz}$ were subjected to catalytic cracking in a fixed-bed reactor at $500^{\circ} \mathrm{C}$ at a liquid hourly space velocity (LHSV) of $1.0 \mathrm{~h}^{-1}$. Nitrogen was used as the carrier gas in the reactor with a pressure of $1.38 \times 10^{5} \mathrm{~Pa}(20 \mathrm{psi})$. A preheater was used to vaporize oils for improved contact with the catalyst. ZSM-5 doped with $10 \mathrm{wt} \%$ of $\mathrm{Zn}$ was used as the catalyst, which was placed in a reactor. The reactor, fixed coaxially in a furnace, was a $508 \mathrm{~mm}$ long stainless steel tube with a $25.4 \mathrm{~mm}$ internal diameter. When oil vapors came in contact with the catalyst, cracking reactions took place. A condenser system setting at $-10^{\circ} \mathrm{C}$ was used to cool the produced oil gases into liquid, considered as upgraded oils. Non-condensable gases, including $\mathrm{H}_{2}, \mathrm{CO}, \mathrm{CO}_{2}$ and light hydrocarbons, were sampled for the composition analysis.

Upgraded camelina oils (UCMO) and upgraded canola oils (UCNO) were a mixture mainly containing hydrocarbons, acids and other oxygenates. They were distilled at $230^{\circ} \mathrm{C}$ in order to separate small molecules with lower boiling points. During distillation, small molecules with boiling point lower than $230^{\circ} \mathrm{C}$ became vapors. These vapors flowed into an overhead condenser system and were cooled back into liquid, considered as mixed hydrocarbons. Large molecules with boiling point higher than $230^{\circ} \mathrm{C}$ were too heavy to vaporize and they were remained as distillation residues in the distillation flask.

\subsection{Data Collection}

The obtained vegetable oils, upgraded oils, mixed hydrocarbons and distillation residues were characterized by testing their dynamic viscosity, $\mathrm{pH}$ value, moisture content, density, main chemical compositions, elemental content, heating value and yield.

Dynamic viscosity of samples was tested using a Visco Analyzer (REOLOGICA Instruments AB Company) at

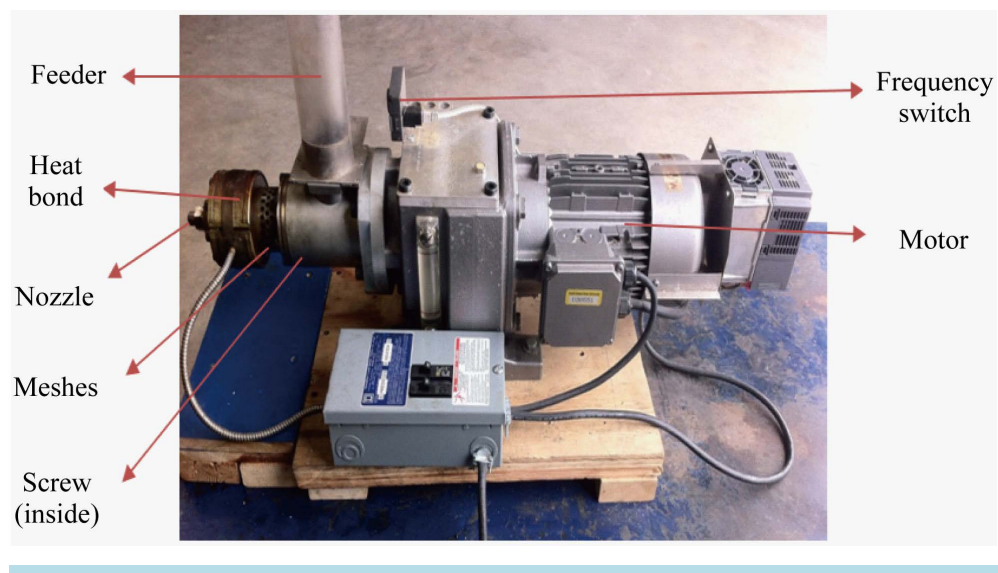

Figure 2. M70 Oil Press. 
$20^{\circ} \mathrm{C}$. The moisture content of samples was measured using a Karl Fischer Titrator V20 (Mettler Toledo Company) at $25^{\circ} \mathrm{C}$, which is within ASTM E1064 standard. PH values were determined using a pH meter (Accumet BASIC AB15, Fisher Scientific) at $25^{\circ} \mathrm{C}$ and $\mathrm{pH}$ testing papers. The density of samples was measured by the ratio of mass to volume of the samples at room temperature [18] [19].

The major chemical compositions of samples were analyzed by Gas Chromatography-Mass Spectrometry (GC-MS) (Agilent GC-7890A and MSD-5975C), that uses hydrogen as a carrier gas with a flow rate of 1.0 $\mathrm{mL} / \mathrm{min}$. The capillary columns are $30 \mathrm{~m} \times 0.25 \mathrm{~mm} \times 0.25 \mu \mathrm{m}$ DB-5MS. The samples were prepared following the derivatization procedure. About $30 \mathrm{mg}$ sample was mixed with $4 \mathrm{~mL}$ hexane. The mixture was shaken for 2 min, and then $2 \mathrm{~mL} \mathrm{BF}_{3}$-methanol, $12 \% \mathrm{w} / \mathrm{w}$, and $2 \mathrm{~mL} \mathrm{CH}_{3} \mathrm{OH}$ were added into the mixture. The mixture was heated at $60^{\circ} \mathrm{C}$ for $10 \mathrm{~min}$ to carry out the simultaneous hydrolysis and methylation. Then, the mixture was cooled down to room temperature and $1 \mathrm{~mL}$ distilled water and $2 \mathrm{~mL}$ hexane were added in order to remove the excess reagents. The organic phase of the mixture was separated by centrifugation at $2500 \mathrm{~g}$ and $25^{\circ} \mathrm{C}$ for 10 min. The organic layer was carefully removed and dried over anhydrous sodium sulfate. Finally, the dry organic phase was injected into the GC-MS equipment. The GC-MS test parameters were as follows. One $\mu \mathrm{L}$ of the dry organic phase was introduced through the injection port operated in a splitless mode at $260^{\circ} \mathrm{C}$. The original column temperature was $175^{\circ} \mathrm{C}$ and the holding time was $6 \mathrm{~min}$. Then, the column temperature became $260^{\circ} \mathrm{C}$ after $5.67 \mathrm{~min}$ at a rate of $15^{\circ} \mathrm{C} / \mathrm{min}$. The holding time at $260^{\circ} \mathrm{C}$ was $15.68 \mathrm{~min}$. The splitless time was $30 \mathrm{~s}$ and the total run time was $27.35 \mathrm{~min}$. The major components were identified through the NIST Mass Spectral library [12] [20].

Carbon $(\mathrm{C})$, hydrogen $(\mathrm{H})$, nitrogen $(\mathrm{N})$, and oxygen $(\mathrm{O})$ content analysis of samples was determined using a CE-440 Elemental Analyzer (Exeter Analytical. Inc.) according to ASTM D4057 standard. Acetanilide was used for calibration. For CHN content analysis, the combustion and reduction temperatures were $980^{\circ} \mathrm{C}$ and $650^{\circ} \mathrm{C}$, respectively. The oxygen and helium pressure were $1.51 \times 10^{5} \mathrm{~Pa}(22 \mathrm{psi})$ and $1.17 \times 10^{5} \mathrm{~Pa}(17 \mathrm{psi})$, respectively. The fill time was between 20 and $50 \mathrm{~s}$. The combustion and purge time were both $20 \mathrm{~s}$. Samples were sealed in a tin capsule and placed in a nickel sleeve. For $\mathrm{O}$ content analysis, the combustion and reduction temperature were $960^{\circ} \mathrm{C}$ and $770^{\circ} \mathrm{C}$, respectively. Only helium was used as the carried gas at $1.17 \times 10^{5} \mathrm{~Pa}(17 \mathrm{psi})$. The combustion and purge time were $40 \mathrm{~s}$ and $50 \mathrm{~s}$, respectively. The sample was sealed in a silver capsule and placed inside a nickel sleeve [21].

The heating value was tested using a C 2000 Calorimeter System (IKA-Works, Inc.) according to the temperature change of water inside the measuring cell, based on ASTM D 4809 standard. About $0.5 \mathrm{~g}$ sample was added in a crucible and placed in a bomb. The sample was ignited with a cotton twist.

The Accelerated Solvent Extractor was used to determine the residual oil content inside the vegetable oilseed meals. About $12 \mathrm{~g}$ meal flours were used in this test and hexane was used as the solvent. The oven temperature was $105^{\circ} \mathrm{C}$ and the static time was $10 \mathrm{~min}$. The rinse volume was $50 \%$ and the purge time was $60 \mathrm{~s}$. The meal flours were mixed with hexane and the oil inside was dissolved. After the oil was dissolved, the mixture of oil and hexane was separated from the solid materials of the meal flours. Then, the oil was separated from hexane by using a distillation system and the oil content remaining in meals was calculated. The oil extraction was completed with three static cycles. The tests for oil content in each residual meal sample were carried out three times [22] [23].

The oil content of oilseeds depends on many factors such as variety, fertilization, growth environment and agricultural production technologies [24]. In this study, the oil content of oilseeds (camelina and canola seeds) was defined as the sum of the oil yield using cold press method and the oil content of residual meals. The oil recovery of oilseeds was defined as the oil yield using cold press method divided by the oil content of oilseeds.

The yields of products were defined by the following equations:

Yield of upgraded oils $=($ mass of upgraded oils/mass of oils feed $) \times 100 \%$

Yield of mixed hydrocarbons $=($ mass of mixed hydrocarbons $/$ mass of upgraded oils feed $) \times 100 \%$

Yield of distillation residues $=($ mass of distillation residues $/$ mass of upgraded oils feed $) \times 100 \%$

\subsection{Statistical Analysis}

In this study, all treatments were conducted in duplicate. The determination of the mean and standard deviation of each parameter was carried out using Microsoft Excel 2013 (Microsoft Corp., Redmond, WA). 


\section{Results and Discussion}

\subsection{Chemical Compositions}

Table 2 shows the major chemical compounds in the camelina and canola oils produced at three different frequencies using the cold press method. The GC-MS analysis of all camelina oils showed that the carbon distribution lied between $\mathrm{C}_{14}$ and $\mathrm{C}_{22}$. Camelina oils, produced at $25 \mathrm{~Hz}, 20 \mathrm{~Hz}$, and $15 \mathrm{~Hz}$, all contained 9,12,15-Octadecatrienoic acid, (Z,Z,Z)-, occupying 82.4\%, 84.5\%, and 78.7\%, respectively. Also, all camelina oils contained cis-11-eicosenoic acid, occupying $5.00 \%-14.5 \%$. However, in camelina oils produced at $15 \mathrm{~Hz}$, the total content of 9,12-Octadecadienoic acid, $(\mathrm{E}, \mathrm{E})$ - $\left(\mathrm{C}_{18}\right)$, tridecanoic acid, 12-methyl- $\left(\mathrm{C}_{14}\right), 8,11,14$-Eicosatrienoic acid $\left(\mathrm{C}_{20}\right)$ and oleic acid $\left(\mathrm{C}_{18}\right)$ was $9.10 \%$. It indicated that the main compositions in camelina oils produced at three frequencies were the same, while other minor compositions were different. The GC-MS analysis of all canola oils showed that the carbon distribution lied between $\mathrm{C}_{9}$ and $\mathrm{C}_{20}$. For canola oils produced at $25 \mathrm{~Hz}, 20 \mathrm{~Hz}$, and $15 \mathrm{~Hz}$, they all contained the same composition of oleic acid, occupying $98.6 \%, 92.5 \%$, and $97.2 \%$, respectively. It also indicated that the main composition in canola oils produced at three frequencies was the same, while other minor compositions were different.

For both camelina and canola oils, they mainly contained fatty acids. Fatty acid profile is one of the important factors that affect the upgrading of vegetable oils for future jet fuel production. Furthermore, unsaturated fatty acids occupied most of the fatty acids in camelina and canola oils. These unsaturated fatty acids varied in the extent of unsaturation and in the carbon chain length. However, the main unsaturated fatty acid in both camelina and canola oils contained the same carbon chain length, $\mathrm{C}_{18}$.

Figure 3 represents the GC-MS chromatograms that resulted from camelina and canola oils cold pressed at three different frequencies. The GC-MS chromatograms showed that all camelina oils had two apparent high peaks. The main chemical composition in all camelina oils was 9,12,15-Octadecatrienoic acid, (Z,Z,Z)-, which was assigned at the highest peak. The 9,12,15-Octadecatrienoic acid, (Z,Z,Z)- was assigned at the peak eluting

Table 2. Main compositions in camelina and canola oils produced at $25 \mathrm{~Hz}, 20 \mathrm{~Hz}$ and $15 \mathrm{~Hz}$.

\begin{tabular}{|c|c|c|c|c|}
\hline \multicolumn{2}{|r|}{ Camelina } & \multicolumn{3}{|c|}{ Canola } \\
\hline & Component & Area $(\%)$ & Component & Area $(\%)$ \\
\hline \multirow{8}{*}{$25 \mathrm{~Hz}$} & Hexadecanoic acid $\left(\mathrm{C}_{16} \mathrm{H}_{32} \mathrm{O}_{2}\right)$ & 0.23 & Hexadecanoic acid $\left(\mathrm{C}_{16} \mathrm{H}_{32} \mathrm{O}_{2}\right)$ & 0.18 \\
\hline & 9,12-Octadecadienoic acid $(\mathrm{Z}, \mathrm{Z})-\left(\mathrm{C}_{18} \mathrm{H}_{32} \mathrm{O}_{2}\right)$ & 0.15 & Oleic acid $\left(\mathrm{C}_{18} \mathrm{H}_{34} \mathrm{O}_{2}\right)$ & 98.6 \\
\hline & 9,12,15-Octadecatrienoic acid, $(\mathrm{Z}, \mathrm{Z}, \mathrm{Z})-\left(\mathrm{C}_{18} \mathrm{H}_{30} \mathrm{O}_{2}\right)$ & 82.4 & Octadecanoic acid $\left(\mathrm{C}_{18} \mathrm{H}_{36} \mathrm{O}_{2}\right)$ & 1.05 \\
\hline & Octadecanoic acid $\left(\mathrm{C}_{18} \mathrm{H}_{36} \mathrm{O}_{2}\right)$ & 1.11 & 9-Octadecenamide, $(\mathrm{Z})-\left(\mathrm{C}_{18} \mathrm{H}_{35} \mathrm{NO}\right)$ & 0.20 \\
\hline & cis-11-eicosenoic acid $\left(\mathrm{C}_{20} \mathrm{H}_{38} \mathrm{O}_{2}\right)$ & 14.5 & & \\
\hline & Methyl 18-methylnonadecanoate $\left(\mathrm{C}_{21} \mathrm{H}_{42} \mathrm{O}_{2}\right)$ & 0.22 & & \\
\hline & 9-Octadecenamide $\left(\mathrm{C}_{18} \mathrm{H}_{35} \mathrm{NO}\right)$ & 0.12 & & \\
\hline & 13-Docosenoic acid, $(\mathrm{Z})-\left(\mathrm{C}_{22} \mathrm{H}_{42} \mathrm{O}_{2}\right)$ & 1.27 & & \\
\hline \multirow{6}{*}{$20 \mathrm{~Hz}$} & Pentadecanoic acid, 14-methyl- $\left(\mathrm{C}_{16} \mathrm{H}_{32} \mathrm{O}_{2}\right)$ & 0.14 & Hexadecanoic acid $\left(\mathrm{C}_{16} \mathrm{H}_{32} \mathrm{O}_{2}\right)$ & 0.89 \\
\hline & $9,12,15$-Octadecatrienoic acid, $(\mathrm{Z}, \mathrm{Z}, \mathrm{Z})-\left(\mathrm{C}_{18} \mathrm{H}_{30} \mathrm{O}_{2}\right)$ & 84.5 & Oleic acid $\left(\mathrm{C}_{18} \mathrm{H}_{34} \mathrm{O}_{2}\right)$ & 92.5 \\
\hline & Octadecanoic acid $\left(\mathrm{C}_{18} \mathrm{H}_{36} \mathrm{O}_{2}\right)$ & 0.80 & Octadecanoic acid $\left(\mathrm{C}_{18} \mathrm{H}_{36} \mathrm{O}_{2}\right)$ & 5.61 \\
\hline & cis-11-eicosenoic acid $\left(\mathrm{C}_{20} \mathrm{H}_{38} \mathrm{O}_{2}\right)$ & 13.7 & cis-11-Eicosenoic acid $\left(\mathrm{C}_{20} \mathrm{H}_{38} \mathrm{O}_{2}\right)$ & 0.62 \\
\hline & Methyl 18-methylnonadecanoate $\left(\mathrm{C}_{21} \mathrm{H}_{42} \mathrm{O}_{2}\right)$ & 0.23 & 9-Octadecenamide, $(\mathrm{Z})-\left(\mathrm{C}_{18} \mathrm{H}_{35} \mathrm{NO}\right)$ & 0.44 \\
\hline & 13-Docosenoic acid $\left(\mathrm{C}_{22} \mathrm{H}_{42} \mathrm{O}_{2}\right)$ & 0.62 & & \\
\hline \multirow{6}{*}{$15 \mathrm{~Hz}$} & Tridecanoic acid, 12-methyl- $\left(\mathrm{C}_{14} \mathrm{H}_{28} \mathrm{O}_{2}\right)$ & 2.96 & Hexadecanoic acid $\left(\mathrm{C}_{16} \mathrm{H}_{32} \mathrm{O}_{2}\right)$ & 0.40 \\
\hline & 9,12-Octadecadienoic acid, $(\mathrm{E}, \mathrm{E})-\left(\mathrm{C}_{18} \mathrm{H}_{32} \mathrm{O}_{2}\right)$ & 3.06 & 9,15-Octadecadienoic acid $\left(\mathrm{C}_{18} \mathrm{H}_{32} \mathrm{O}_{2}\right)$ & 0.71 \\
\hline & $9,12,15$-Octadecatrienoic acid, $(\mathrm{Z}, \mathrm{Z}, \mathrm{Z})-\left(\mathrm{C}_{18} \mathrm{H}_{30} \mathrm{O}_{2}\right)$ & 78.7 & Oleic acid $\left(\mathrm{C}_{18} \mathrm{H}_{34} \mathrm{O}_{2}\right)$ & 97.2 \\
\hline & Oleic acid $\left(\mathrm{C}_{18} \mathrm{H}_{34} \mathrm{O}_{2}\right)$ & 1.47 & 6-Nonynoic acid $\left(\mathrm{C}_{9} \mathrm{H}_{14} \mathrm{O}_{2}\right)$ & 0.28 \\
\hline & cis-11-eicosenoic acid $\left(\mathrm{C}_{20} \mathrm{H}_{38} \mathrm{O}_{2}\right)$ & 5.00 & & \\
\hline & $8,11,14$-Eicosatrienoic acid $\left(\mathrm{C}_{20} \mathrm{H}_{34} \mathrm{O}_{2}\right)$ & 1.61 & & \\
\hline
\end{tabular}




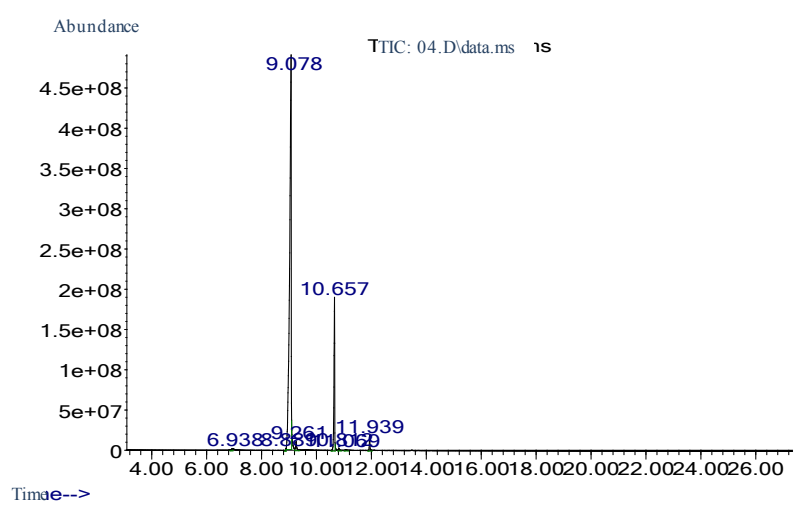

(a)

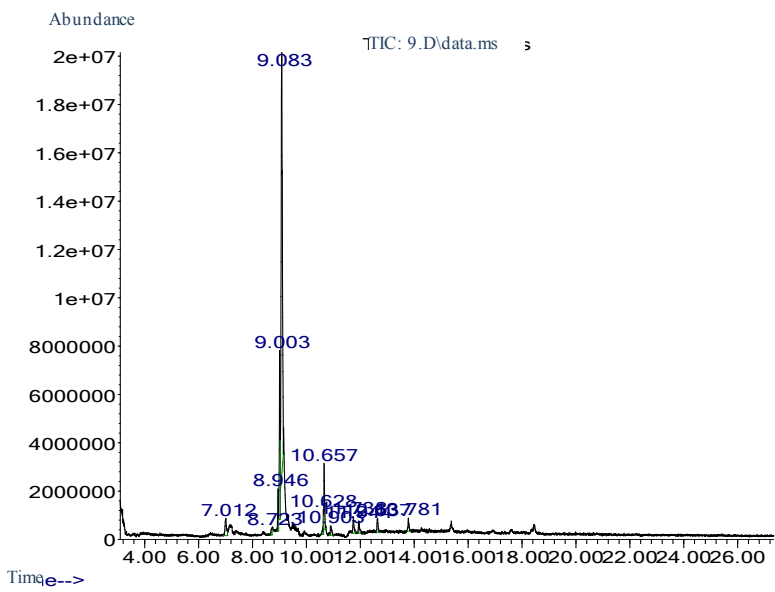

(c)

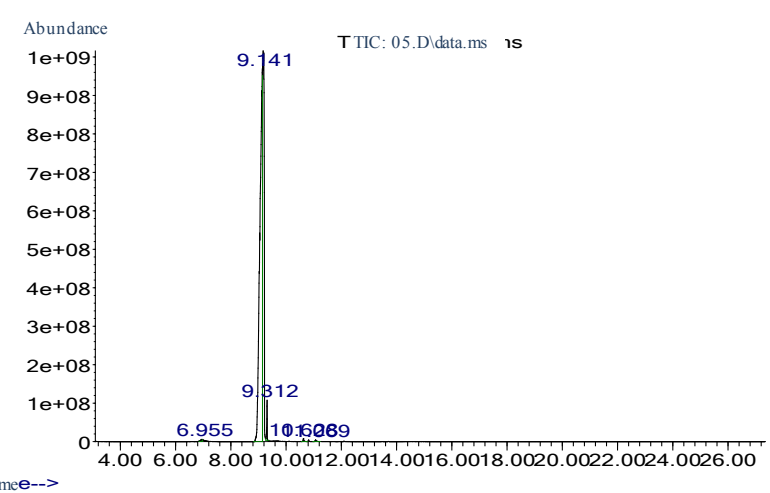

(e)

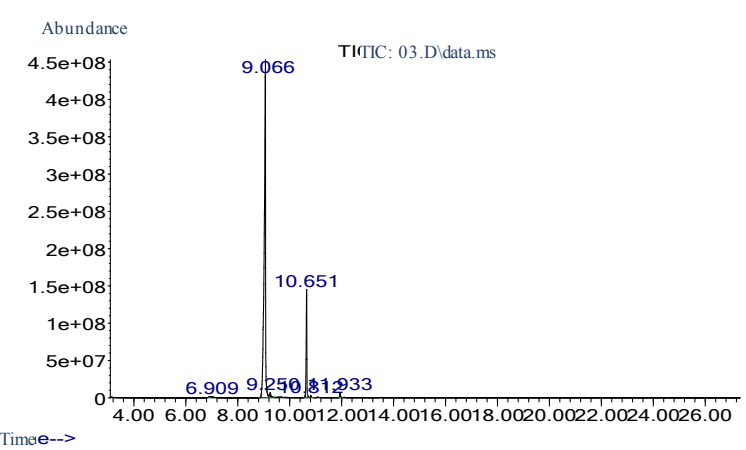

(b)

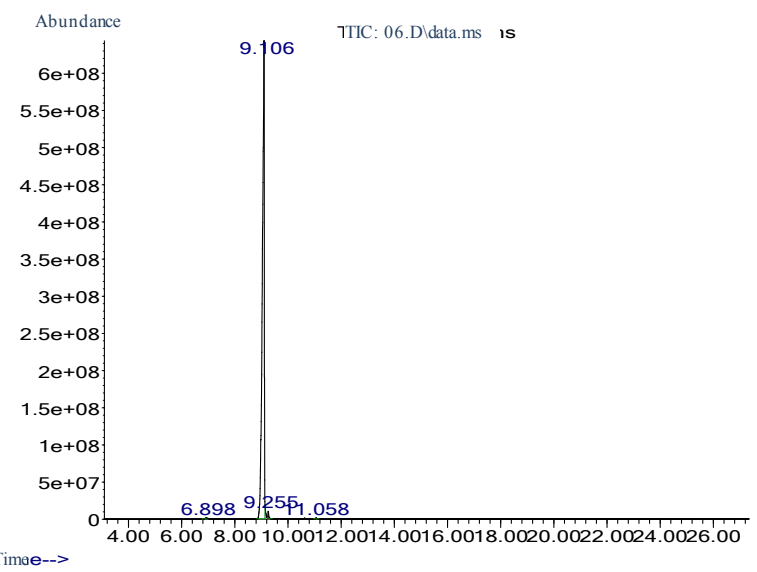

(d)

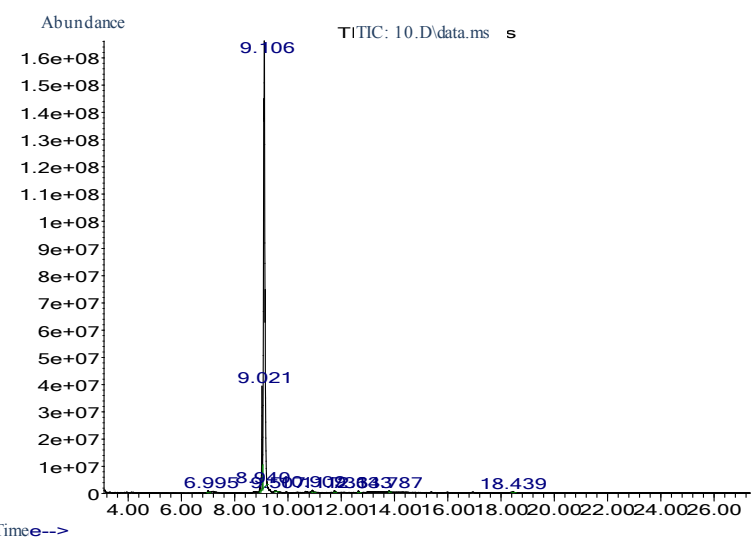

(f)

Figure 3. GC-MS chromatograms of oil samples: (a) camelina oil produced at $25 \mathrm{~Hz}$; (b) camelina oil produced at $20 \mathrm{~Hz}$; (c) camelina oil produced at $15 \mathrm{~Hz}$; (d) canola oil produced at $25 \mathrm{~Hz}$; (e) canola oil produced at $20 \mathrm{~Hz}$; (f) canola oil produced at $15 \mathrm{~Hz}$.

of $9.078 \mathrm{~min}, 9.066 \mathrm{~min}$, and $9.083 \mathrm{~min}$ for camelina oils produced at $25 \mathrm{~Hz}, 20 \mathrm{~Hz}$, and $15 \mathrm{~Hz}$, respectively. The second highest peak was assigned as cis-11-eicosenoic acid at about $10.65 \mathrm{~min}$. Similarly, all canola oils had a same high peak, which was assigned as oleic acid. For canola oils produced at $25 \mathrm{~Hz}, 20 \mathrm{~Hz}$ and $15 \mathrm{~Hz}$, oleic acid was assigned at the peak eluting of $9.106 \mathrm{~min}, 9.141 \mathrm{~min}$, and $9.106 \mathrm{~min}$, respectively. The properties of the fatty acids, such as branching of the chain, chain length and degree of unsaturation, could influence the bio-fuel quality. Both 9,12,15-Octadecatrienoic acid, (Z,Z,Z)- and oleic acid were found suitable for hydrocar- 
bon fuel production [25]-[27]. For camelina oils produced at $15 \mathrm{~Hz}$, there appeared some small peaks after 12.0 min. For canola oils produced at $15 \mathrm{~Hz}$, there also appeared some small peaks after $11.1 \mathrm{~min}$. This might be due to the lower frequency that caused a slower extraction of oilseeds.

\subsection{Elemental Content}

Table 3 lists the CHNO content of camelina and canola oils produced at three frequencies. Carbon was a main component in all oil samples. The nitrogen content of all oil samples was lower than $0.8 \%$, which indicates a low level of phospholipid. For all camelina oils produced at the three frequencies, the carbon content was the same. Also, their $\mathrm{H} / \mathrm{C}$ molar ratios were between 1.81 and 1.82. Canola oils had a lower carbon content and higher hydrogen content than camelina oils. The $\mathrm{H} / \mathrm{C}$ molar ratios of canola oils were between 1.86 and 1.87 . It means the frequency during the cold press processing of camelina and canola seeds had less effect on the $\mathrm{CH}$ content. The $\mathrm{H} / \mathrm{C}$ molar ratios of both camelina and canola oils were lower than that of petroleum product, which was 2.0.

Vegetable oils contain oxygen atoms in the structure of hydrocarbons. The oxygen content influences the specific energy and the combustion [28]. During vegetable oil upgrading, removing oxygen is a significant aim. From Table 3, the oxygen contents of camelina oils cold pressed at different frequencies were between $11.7 \%$ and $12.6 \%$, indicating that they had no big difference. Similarly, the frequency during the cold press processing of oilseeds had less effect on the oxygen content of canola oils. For bio-jet fuel, the oxygen content is below $1.0 \%$ [29]. Therefore, the oils need to be further treated in order to reduce the oxygen content.

\subsection{Physical Properties}

The densities of camelina oils produced at different frequencies, shown in Table 4, were quite similar. For canola oils, the density values showed a minor difference. Camelina oil produced at $20 \mathrm{~Hz}$ had the highest density, which was $0.90 \mathrm{~g} / \mathrm{mL}$. The density of oil is related to its chemical structure and composition. During the cold press processing of canola oilseeds, the temperatures below the heat bond were slightly different. For canola oils produced at $20 \mathrm{~Hz}$, the temperature was between $100.8^{\circ} \mathrm{C}$ and $103.7^{\circ} \mathrm{C}$. However, the temperatures were within the range of $94.9^{\circ} \mathrm{C}-98.2^{\circ} \mathrm{C}$ at $15 \mathrm{~Hz}$ and $97.1^{\circ} \mathrm{C}-98.8^{\circ} \mathrm{C}$ at $25 \mathrm{~Hz}$, respectively. The slight difference in temperatures possibly occurred due to the different chemical structure and composition of oils, thus leading to the different densities. However, the densities of both camelina and canola oils were between 0.87 and $0.90 \mathrm{~g} / \mathrm{mL}$, which were higher than that of jet fuel $(0.81 \mathrm{~g} / \mathrm{mL})[30]-[32]$.

The $\mathrm{pH}$ values of camelina and canola oils produced at different frequencies are shown in Table 4. Acid value is usually used to quantify the amount of acids in samples. It is a more standardized measurement than $\mathrm{pH}$ value. However, only the $\mathrm{pH}$ values were measured in this study to qualitative the amount of organic acid in samples due to the limitation of current equipment conditions. In the future research, the acid value of samples will be determined. All the oils produced from camelina and canola oilseeds showed a mild acidity. The $\mathrm{pH}$ values of camelina oil produced at $15 \mathrm{~Hz}$ and $25 \mathrm{~Hz}$ were the same, while the $\mathrm{pH}$ value of camelina oil produced at $20 \mathrm{~Hz}$ was slightly different from them. For canola oils produced at different frequencies, the $\mathrm{pH}$ values were not very different and they varied between 3.75 and 4.09 . At a low temperature range of $94.9^{\circ} \mathrm{C}-108.9^{\circ} \mathrm{C}$ during the cold press machine process, mechanical aspects may have less effect on the $\mathrm{pH}$. The acidity of vegetable oils reflects the content of free fatty acids, which are produced from chemical or enzymatic (lipolytic enzymes) reactions that cause the split of triglycerides, monoglycerides and diglycerides [2]. Since camelina oils had a different content

Table 3. The CHNO content of oil samples.

\begin{tabular}{cccccc}
\hline Oils & Frequency $(\mathrm{Hz})$ & $\mathrm{C}(\mathrm{wt} \%)$ & $\mathrm{H}(\mathrm{wt} \%)$ & $\mathrm{N}(\mathrm{wt} \%)$ & $0.40 \pm 0.25$ \\
\hline Camelina & 25 & $78.4 \pm 0.05$ & $11.9 \pm 0.01$ & $11.9 \pm 0.01$ & $0.29 \pm 0.07$ \\
Camelina & 20 & $78.4 \pm 0.04$ & $11.8 \pm 0.04$ & $0.71 \pm 0.21$ & $12.4 \pm 0.78$ \\
Camelina & 15 & $78.4 \pm 0.01$ & $12.1 \pm 0.01$ & $11.7 \pm 0.76$ & $0.57 \pm 0.07$ \\
Canola & 25 & $77.7 \pm 0.07$ & $12.0 \pm 0.04$ & $0.55 \pm 0.42$ \\
Canola & 20 & $77.4 \pm 0.06$ & $12.1 \pm 0.16$ & $0.51 \pm 0.35$ \\
Canola & 15 & & & $11.2 \pm 0.47$ & $12.5 \pm 0.62$ \\
\hline
\end{tabular}


Table 4. The physical properties of oil samples.

\begin{tabular}{ccccccc}
\hline Oils & Frequency $(\mathrm{Hz})$ & Density $(\mathrm{g} / \mathrm{mL})$ & $\mathrm{pH}$ Value & Moisture $(\%)$ & Viscosity $(\mathrm{cP})$ & Heating Value $(\mathrm{MJ} / \mathrm{Kg})$ \\
\hline Camelina & 25 & $0.88 \pm 0.04$ & $5.14 \pm 0.13$ & $0.06 \pm 0.01$ & $58.9 \pm 0.06$ & $39.7 \pm 0.06$ \\
Camelina & 20 & $0.89 \pm 0.02$ & $5.44 \pm 0.38$ & $0.08 \pm 0.01$ & $59.4 \pm 0.11$ & $39.4 \pm 0$ \\
Camelina & 15 & $0.89 \pm 0.01$ & $5.14 \pm 0.25$ & $0.06 \pm 0$ & $59.7 \pm 0.04$ & $39.6 \pm 0.05$ \\
Canola & 25 & $0.87 \pm 0.02$ & $3.80 \pm 0.63$ & $0.11 \pm 0$ & $76.2 \pm 0.09$ & $39.7 \pm 0.02$ \\
Canola & 20 & $0.90 \pm 0.01$ & $3.75 \pm 0.39$ & $0.11 \pm 0$ & $76.5 \pm 0.06$ & $39.7 \pm 0.06$ \\
Canola & 15 & $0.89 \pm 0.01$ & $4.09 \pm 0.86$ & $0.10 \pm 0$ & $77.9 \pm 0.04$ & $39.7 \pm 0$ \\
\hline
\end{tabular}

of fatty acids from canola oils, there was a big difference between the $\mathrm{pH}$ values of these two types of oils.

The moisture content of oil samples at different frequencies is represented in Table 4. The free or bonded water in the oils results in the formation of free fatty acids, which can corrode the engine and fuel storage tank [26] [27]. For both camelina and canola oils, their water contents were very low, equal to or below $0.11 \%$. The moisture content of Jet A/Jet A-1 was less than $0.1 \%$, indicating that vegetable oils have potential for future jet fuel production [29] [33]. For both camelina and canola oils, the frequency had a minor effect on the moisture content of oils. Small amounts of water left in oils could help improve their mobility. The water in oils may come from the water within camelina seeds and canola seeds. Camelina oils contained less water than canola oils, which may result from the lower water content in camelina seeds compared to canola seeds. Most of the water in oilseeds had been evaporated during the cold press processing due to the temperature varying between $94.9^{\circ} \mathrm{C}$ and $108.9^{\circ} \mathrm{C}$. Also, some water may be left in the extruded meals. The low moisture content of oils may be connected with their high viscosity, which was stated below.

The dynamic viscosity of oils is shown in Table 4. Viscosity is one of the determining factors of fuel quality and use. It may significantly influence the performance of the pump and fuel injector in engines. Viscosity is affected largely by the chemical structure of oils, such as the fatty acid profile, triglyceride composition, chain length, chain branching, degree of saturation, molecular configuration (cis-trans, conjugation), oxidation presence and degradation products. Camelina oils produced at different frequencies had similar viscosities. Also, the viscosities for canola oils had minor differences. However, the viscosity of camelina oils was lower than that of canola oils. The main chemical composition in camelina and canola oils was 9,12,15-Octadecatrienoic acid, (Z,Z,Z)- $\left(\mathrm{C}_{18} \mathrm{H}_{30} \mathrm{O}_{2}\right)$ and oleic acid $\left(\mathrm{C}_{18} \mathrm{H}_{34} \mathrm{O}_{2}\right)$, respectively. The smaller chemical molecule size in camelina oils may result in the lower viscosity. Compared to the dynamic viscosity of Jet A/Jet A-1, $2 \mathrm{cP}$ measured at $25^{\circ} \mathrm{C}$, the viscosities of camelina and canola oils were much higher [29]. Camelina and canola oils contained large chemical molecules and complicated molecular structures, which caused their high viscosity. It indicates that the direct use of vegetable oils as fuel is impractical and the oils need to be upgraded for the future bio-jet fuel use.

The heating values of oils are shown in Table 4. All of the heating values of camelina and canola oils had no significant difference. Perhaps the similar oxygen contents of them led to the similar heating values. The net heat value of Jet A/Jet A-1 was $43.2 \mathrm{MJ} / \mathrm{Kg}$, indicating the vegetable oils have to be upgraded before being used as bio-fuels in the future [30].

\subsection{Oil Recovery}

Figure 4 shows the oil recovery of camelina and canola seeds cold pressed at different frequencies. The highest oil recovery of $88.2 \%$ was achieved when camelina seeds were cold pressed at $15 \mathrm{~Hz}$. The oil recovery of camelina seeds cold pressed at $20 \mathrm{~Hz}$ and $25 \mathrm{~Hz}$ was $88.0 \%$ and $86.7 \%$, respectively. For canola seeds cold pressed at $15 \mathrm{~Hz}, 20 \mathrm{~Hz}$ and $25 \mathrm{~Hz}$, the oil recovery was $84.1 \%, 83.6 \%$ and $83.3 \%$, respectively. It is obvious that for both camelina and canola seeds, the oil recovery increased with the decrease of frequency. A lower frequency led to a slower extraction of oilseeds, which might increase the oil yield, thus resulting in a higher oil recovery. However, a higher oil recovery was obtained for camelina seeds, compared to canola seeds. The processing temperature was within a range of $99.9^{\circ} \mathrm{C}-108.9^{\circ} \mathrm{C}$ during cold press processing of camelina seeds. For canola oils produced at three frequencies, the processing temperature was between $94.9^{\circ} \mathrm{C}$ and $103.7^{\circ} \mathrm{C}$. The minor difference of the processing temperature range might be contributed to the slightly different shell hardness of camelina and canola seeds. Under this situation, the oil recovery of camelina and canola seeds became different. During cold press processing of vegetable oilseeds, meal was extracted as a co-product. For cold press processing of camelina 


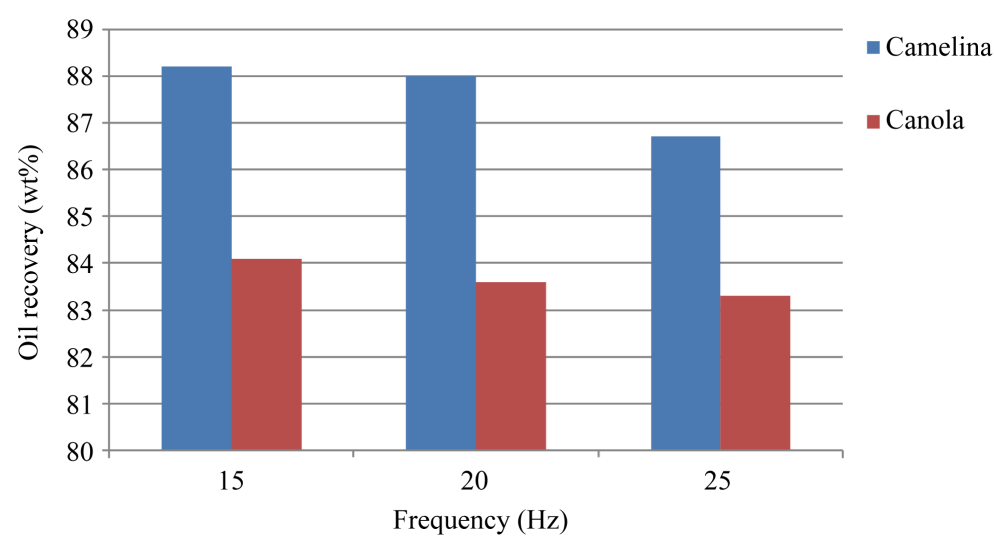

Figure 4. Oil recovery (wt $\%)$ of camelina and canola seeds.

seeds at these three frequencies, the meal yield was between $61.8 \%$ and $62.7 \%$. For canola seeds extracted at these three frequencies, the meal yield was in a range of $61.1 \%-61.5 \%$. The oilseed meals with high yields have potential as food for animals, such as fish and cattle.

\subsection{Oil Content of Residual Meals}

Table 5 lists the oil content of residual meal extracted from camelina and canola seeds at $15 \mathrm{~Hz}$. The solvent extraction method was capable of recovering about $99 \%$ oil contained in the oilseeds [34]. In this study, the oil content of residual meals was defined as the measured oil content of residual meals using solvent extraction method divided by $99 \%$. The oil content of residual camelina meal was lower than that of residual canola meal. This is maybe because the hulls of camelina and canola seeds were different, thus resulting in different oil contents in the residual meals.

\subsection{Preliminary Tests of Oil Upgrading}

\subsubsection{Physiochemical Characterization}

This is a preliminary study investigating the upgrading of camelina and canola oils, which were cold pressed at $15 \mathrm{~Hz}$. In the present study, it is aimed to find out an effective cold press for oil extraction from camelina and canola seeds. Comparing the oil extraction from these two feed stocks using the cold press machine at the three different frequencies, the highest oil recovery was obtained for both feed stocks when the cold press ran at 15 $\mathrm{Hz}$. In addition, the cold press running frequencies had slight influence on the oil properties. Therefore, the frequency of $15 \mathrm{~Hz}$ during the cold press processing of oilseeds was identified as the optimal processing parameter. Table 6 shows the main chemical compositions of products after catalytic cracking of camelina and canola oils at $500^{\circ} \mathrm{C}$. Both upgraded camelina oils and upgraded canola oils mainly contained fatty acids, hydrocarbons, and esters. The total fatty acids content of upgraded camelina oils and upgraded canola oils was $59.84 \%$ and $76.85 \%$, respectively. This meant that a certain amount of oxygen was removed during the catalytic cracking of camelina and canola oils. After distillation, the main component in both camelina mixed hydrocarbons (CMMH) and canola mixed hydrocarbons (CNMH) was hydrocarbons, which occupied between $70.53 \%$ and $74.67 \%$. As shown in Figure 5, for camelina oil upgrading, apparent decreases in peak areas and peak heights (after 12.225 min) were observed in the GC-MS profiles of camelina mixed hydrocarbons than upgraded camelinaoils. Similarly, for canola oil upgrading, apparent decreases in peak areas and peak heights (after $12.133 \mathrm{~min}$ ) were observed in the GC-MS profiles of canola mixed hydrocarbons than upgraded canola oils. It indicated that low-moleculeweight compounds were separated and became mixed hydrocarbons after the distillation treatment [30]. For canola distillation residues (CNDR), they contained similar main components as upgraded canola oils. More obviously, camelina distillation residues (CMDR) contained similar main components as upgraded camelina oils. However, some tars might be generated during the upgrading process, which then remained in the distillation residues after the distillation treatment. This might cause a much higher viscosity of distillation residues than upgraded oils, as shown in Table 7.

Table 7 shows the physical properties of products during the upgrading of camelina and canola oils, which 
Table 5. The oil content of residual meals.

\begin{tabular}{cc}
\hline Oilseeds & Oil Content of Residual Meal $(\%)$ \\
\hline Camelina & $4.90 \pm 1.55$ \\
Canola & $7.07 \pm 1.21$ \\
\hline
\end{tabular}

Table 6. Main chemical compositions of upgraded oils, mixed hydrocarbons and distillation residues produced from camelina and canola oils.

\begin{tabular}{|c|c|c|c|c|}
\hline \multicolumn{3}{|c|}{ Camelina } & \multicolumn{2}{|l|}{ Canola } \\
\hline & Component & Area $(\%)$ & Component & Area $(\%)$ \\
\hline \multirow[t]{8}{*}{ Upgraded oils } & $5,8,11,14$-Eicosatetranoic acid $\left(\mathrm{C}_{20} \mathrm{H}_{24} \mathrm{O}_{2}\right)$ & 7.28 & Hexadecanoic acid $\left(\mathrm{C}_{16} \mathrm{H}_{32} \mathrm{O}_{2}\right)$ & 7.66 \\
\hline & Linoleic acid ethyl ester $\left(\mathrm{C}_{20} \mathrm{H}_{36} \mathrm{O}_{2}\right)$ & 24.5 & Oleic acid $\left(\mathrm{C}_{18} \mathrm{H}_{34} \mathrm{O}_{2}\right)$ & 58.4 \\
\hline & 10,12,14-Nonacosatriynoic acid $\left(\mathrm{C}_{29} \mathrm{H}_{46} \mathrm{O}_{2}\right)$ & 7.06 & 16-Octadecenoic acid $\left(\mathrm{C}_{18} \mathrm{H}_{34} \mathrm{O}_{2}\right)$ & 8.01 \\
\hline & cis-11-Eicosenoic acid $\left(\mathrm{C}_{20} \mathrm{H}_{38} \mathrm{O}_{2}\right)$ & 34.3 & Methyl 11-eicosenoate $\left(\mathrm{C}_{21} \mathrm{H}_{42} \mathrm{O}_{2}\right)$ & 2.07 \\
\hline & Eicosanoic acid $\left(\mathrm{C}_{20} \mathrm{H}_{40} \mathrm{O}_{2}\right)$ & 11.2 & Eicosanoic acid $\left(\mathrm{C}_{20} \mathrm{H}_{40} \mathrm{O}_{2}\right)$ & 2.78 \\
\hline & $\begin{array}{l}\text { 2,6,10,14,18,22-Tetracosahexaene, } \\
\text { 2,6,10,15,19,23-hexamethyl-, (all-E)-, } \\
\text { didehydro deriv. }\left(\mathrm{C}_{30} \mathrm{H}_{48}\right)\end{array}$ & 4.44 & 9-Octadecenamide, $(\mathrm{Z})-\left(\mathrm{C}_{18} \mathrm{H}_{35} \mathrm{NO}\right)$ & 17.2 \\
\hline & & & 13-Hexacosyne $\left(\mathrm{C}_{26} \mathrm{H}_{50}\right)$ & 2.02 \\
\hline & & & Ergosta-4,22-dien-3-one $\left(\mathrm{C}_{28} \mathrm{H}_{44} \mathrm{O}\right)$ & 1.93 \\
\hline \multirow[t]{8}{*}{$\begin{array}{c}\text { Mixed } \\
\text { hydrocarbons }\end{array}$} & Hexadecanoic acid $\left(\mathrm{C}_{16} \mathrm{H}_{32} \mathrm{O}_{2}\right)$ & 3.87 & Hexadecanoic acid $\left(\mathrm{C}_{16} \mathrm{H}_{32} \mathrm{O}_{2}\right)$ & 9.08 \\
\hline & Octadecanoic acid $\left(\mathrm{C}_{18} \mathrm{H}_{36} \mathrm{O}_{2}\right)$ & 2.43 & Cyclododecene, $(\mathrm{Z})-\left(\mathrm{C}_{12} \mathrm{H}_{22}\right)$ & 1.07 \\
\hline & 2-Methyl-Z,Z-3,13-octadecadienol $\left(\mathrm{C}_{19} \mathrm{H}_{36} \mathrm{O}\right)$ & 0.80 & Oleic acid $\left(\mathrm{C}_{18} \mathrm{H}_{34} \mathrm{O}_{2}\right)$ & 7.90 \\
\hline & Oleic acid $\left(\mathrm{C}_{18} \mathrm{H}_{34} \mathrm{O}_{2}\right)$ & 17.5 & Octadecanoic acid $\left(\mathrm{C}_{18} \mathrm{H}_{36} \mathrm{O}_{2}\right)$ & 3.82 \\
\hline & 9-Octadecenamide, $(\mathrm{Z})-\left(\mathrm{C}_{18} \mathrm{H}_{35} \mathrm{NO}\right)$ & 1.07 & 6-Octen-1-ol, 3,7-dimethyl- $\left(\mathrm{C}_{10} \mathrm{H}_{20} \mathrm{O}\right)$ & 1.54 \\
\hline & 9-Hexadecenoic acid, $(\mathrm{Z})-\left(\mathrm{C}_{16} \mathrm{H}_{30} \mathrm{O}_{2}\right)$ & 3.73 & 9-Octadecenamide, $(\mathrm{Z})-\left(\mathrm{C}_{18} \mathrm{H}_{35} \mathrm{NO}\right)$ & 3.00 \\
\hline & $1,5,9,13$-Tetradecatetraene $\left(\mathrm{C}_{14} \mathrm{H}_{22}\right)$ & 0.83 & Hexane, 2,3-dimethyl- $\left(\mathrm{C}_{8} \mathrm{H}_{18}\right)$ & 73.6 \\
\hline & Hexane, 2,3-dimethyl- $\left(\mathrm{C}_{8} \mathrm{H}_{18}\right)$ & 69.7 & & \\
\hline \multirow[t]{9}{*}{$\begin{array}{l}\text { Distillation } \\
\text { residues }\end{array}$} & $5,8,11,14$-Eicosatetranoic acid $\left(\mathrm{C}_{20} \mathrm{H}_{24} \mathrm{O}_{2}\right)$ & 5.48 & Hexadecanoic acid $\left(\mathrm{C}_{16} \mathrm{H}_{32} \mathrm{O}_{2}\right)$ & 1.81 \\
\hline & $\alpha-\mathrm{N}-\mathrm{Nomethadol}\left(\mathrm{C}_{20} \mathrm{H}_{27} \mathrm{NO}\right)$ & 1.74 & Oleic acid $\left(\mathrm{C}_{18} \mathrm{H}_{34} \mathrm{O}_{2}\right)$ & 91.2 \\
\hline & Linoleic acid ethyl ester $\left(\mathrm{C}_{20} \mathrm{H}_{36} \mathrm{O}_{2}\right)$ & 28.8 & Octadecanoic acid $\left(\mathrm{C}_{18} \mathrm{H}_{36} \mathrm{O}_{2}\right)$ & 1.60 \\
\hline & 10,12,14-Nonacosatriynoic acid $\left(\mathrm{C}_{29} \mathrm{H}_{46} \mathrm{O}_{2}\right)$ & 5.20 & 1,15-Hexadecadiene $\left(\mathrm{C}_{16} \mathrm{H}_{30}\right)$ & 1.64 \\
\hline & Phorbol $\left(\mathrm{C}_{20} \mathrm{H}_{28} \mathrm{O}_{6}\right)$ & 2.80 & Oleyl Alcohol $\left(\mathrm{C}_{18} \mathrm{H}_{36} \mathrm{O}\right)$ & 3.77 \\
\hline & cis-11-Eicosenoic acid $\left(\mathrm{C}_{20} \mathrm{H}_{38} \mathrm{O}_{2}\right)$ & 16.2 & & \\
\hline & Eicosanoic acid $\left(\mathrm{C}_{20} \mathrm{H}_{40} \mathrm{O}_{2}\right)$ & 9.03 & & \\
\hline & $\begin{array}{l}\text { 2,6,10,14,18,22-Tetracosahexaene, } \\
\text { 2,6,10,15,19,23-hexamethyl-, (all-E)-, } \\
\text { didehydro deriv. }\left(\mathrm{C}_{30} \mathrm{H}_{48}\right)\end{array}$ & 7.53 & & \\
\hline & i-Propyl 5,9,17-hexacosatrenoate $\left(\mathrm{C}_{29} \mathrm{H}_{52} \mathrm{O}_{2}\right)$ & 0.86 & & \\
\hline
\end{tabular}

were cold pressed at $15 \mathrm{~Hz}$. Raw camelina and canola oils were upgraded in order to improve their undesirable properties. After upgrading, there was a small decrease in density. The larger molecules were broken into smaller ones during the catalytic cracking process, which may result in the lower density. The viscosities of upgraded oils decreased greatly than raw oils. The lower viscosity made the oil easier for subsequent operating and pumping. In addition, the heating values of upgraded oils increased. However, the moisture content increased due to the water production during the upgrading process. After a treatment of distillation, the densities and viscosities of mixed hydrocarbons decreased further. Also, the moisture content of mixed hydrocarbons became 
Table 7. Physical properties of products during the oil upgrading.

\begin{tabular}{cccccc}
\hline Sample & Density $(\mathrm{g} / \mathrm{mL})$ & $\mathrm{pH}$ Value & Moisture $(\%)$ & Viscosity $(\mathrm{cP})$ & Heating Value $(\mathrm{MJ} / \mathrm{Kg})$ \\
\hline UCMO & $0.86 \pm 0$ & $5.72 \pm 0.06$ & $0.42 \pm 0.04$ & $2.75 \pm 0.04$ & $42.6 \pm 0.14$ \\
CMMH & $0.79 \pm 0.02$ & $5.25 \pm 0.07$ & $0.08 \pm 0.01$ & $0.97 \pm 0$ & $42.6 \pm 0.03$ \\
CMDR & $0.87 \pm 0.01$ & $3.80 \pm 0.17$ & $0.24 \pm 0.01$ & $53.2 \pm 0.71$ & $42.8 \pm 0.01$ \\
UCNO & $0.85 \pm 0$ & $3.79 \pm 0.12$ & $0.33 \pm 0.01$ & $1.34 \pm 0.01$ & $41.7 \pm 0.25$ \\
CNMH & $0.82 \pm 0.01$ & $5.30 \pm 0.14$ & $0.10 \pm 0.01$ & $1.05 \pm 0.01$ & $41.9 \pm 0.21$ \\
CNDR & $0.89 \pm 0$ & $3.49 \pm 0.09$ & $0.11 \pm 0.02$ & $116.5 \pm 0.71$ & $41.0 \pm 0.04$ \\
\hline
\end{tabular}

lower than upgraded oils. These three properties were considered as good signs. The density, viscosity and moisture content of camelina mixed hydrocarbons have met the requirements of bio-jet fuel. The viscosity and moisture content of canola mixed hydrocarbons have met the requirements of bio-jet fuel. It indicates that the catalytic cracking method is effective to convert vegetable oils to mixed hydrocarbons, which have the potential for future bio-jet fuel production. For distillation residues, they had lower $\mathrm{pH}$ values and moisture content, and higher densities and viscosities than upgraded oils. In the future, the distillation residues could be treated further, such as a second catalytic cracking, for bio-fuels production.

\subsubsection{The Yields}

Figure 6 shows the yields of upgraded camelina oils, camelina mixed hydrocarbons, camelina distillation residues, upgraded canola oils, canola mixed hydrocarbons, and canola distillation residues during the catalytic cracking and distillation process. The yields of upgraded camelina oils and upgraded canola oils cracked at $500^{\circ} \mathrm{C}$ were both higher than $60 \%$. After distillation, the yields of camelina mixed hydrocarbons and canola mixed hydrocarbons were $21.9 \%$ and $26.7 \%$, respectively. It indicated the distillation efficiency might be affected by the chemical compositions in upgraded oils.

\subsubsection{GC Analysis}

Atypical GC analysis for the non-condensable gases produced from catalytically cracking camelina and canola oils at $500^{\circ} \mathrm{C}$ is shown in Figure 7. For TCD signal analysis, there were noise peaks between $\mathrm{H}_{2}$ peak and $\mathrm{CO}_{2}$ peak. These noise peaks were not drawn in the TCD signal figures in this study. Inside the ZSM-5-Zn-10\% catalyst, there were several reactions occurring, such as dehydration, decarbonylation, decarboxylation, and isomerization. These reactions can convert carbon and hydrogen into olefins and aromatics; and they can remove oxygen as $\mathrm{CO}, \mathrm{CO}_{2}$, and $\mathrm{H}_{2} \mathrm{O}[35]$.

During the catalytic cracking of camelina and canola oils, the non-condensable gases contained $\mathrm{CH}_{4}, \mathrm{C}_{2} \mathrm{H}_{6}$, $\mathrm{C}_{2} \mathrm{H}_{4}, \mathrm{C}_{3} \mathrm{H}_{8}, \mathrm{C}_{3} \mathrm{H}_{6}, \mathrm{C}_{4} \mathrm{H}_{10}, \mathrm{C}_{5} \mathrm{H}_{12}, \mathrm{H}_{2}, \mathrm{CO}_{2}$ and $\mathrm{CO}$. The production of $\mathrm{CH}_{4}$ indicated that ZSM-5-Zn-10\% was able to crack and convert fatty acids into the smallest fraction of hydrocarbons. The production of $\mathrm{H}_{2}$ resulted from the dehydrogenation reaction. However, some $\mathrm{H}_{2}$ was attracted to unstable species to produce more stable products. The production of $\mathrm{CO}$ and $\mathrm{CO}_{2}$ were contributed to some light olefins, such as $\mathrm{C}_{3} \mathrm{H}_{6}$ and $\mathrm{C}_{2} \mathrm{H}_{4}$.

During the catalytic cracking of camelina oils, the total organic compositions, $\mathrm{C}_{1}$ to $\mathrm{C}_{5}$, occupied an area content of $12.14 \%$. The area contents of $\mathrm{H}_{2}, \mathrm{CO}_{2}$, and $\mathrm{CO}$ were $5.25 \%$. During the catalytic cracking of canola oils, the total organic compositions occupied an area content of $21.50 \%$. The area contents of $\mathrm{H}_{2}, \mathrm{CO}_{2}$, and $\mathrm{CO}$ were $11.76 \%$. It indicated that there were more decarboxylation and decarbonylation occurring during the catalytic cracking of canola oils at $500^{\circ} \mathrm{C}$. The $\mathrm{H}_{2}$ and $\mathrm{CO}$ generated during the catalytic cracking of camelina and canola oils have the potential for future syngas application.

\section{Conclusions}

The highest oil recovery for camelina and canola seeds using the cold press method is $88.2 \%$ and $84.1 \%$, respectively. Also, more than $60 \%$ of meals are obtained during the cold press processing of these two seeds. The meals could be analyzed and treated in the future as food for animals. The density, $\mathrm{pH}$ value, moisture, heating value and oxygen content of both camelina and canola oils, produced at different frequencies, have no significant difference because of the relative low processing temperature during screw pressing. During the cold press of camelina and canola oilseeds, the frequency of $15 \mathrm{~Hz}$ is identified as the optimal processing parameter. 


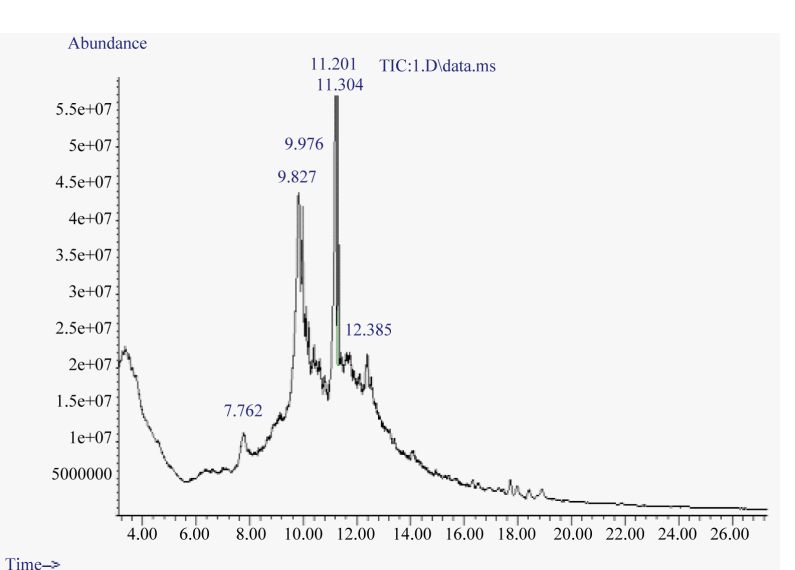

(a)

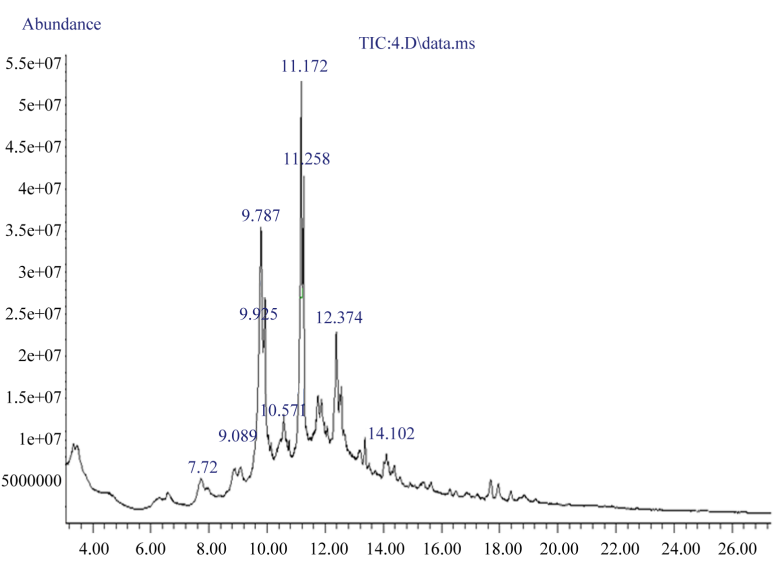
Time $\rightarrow$

(c)

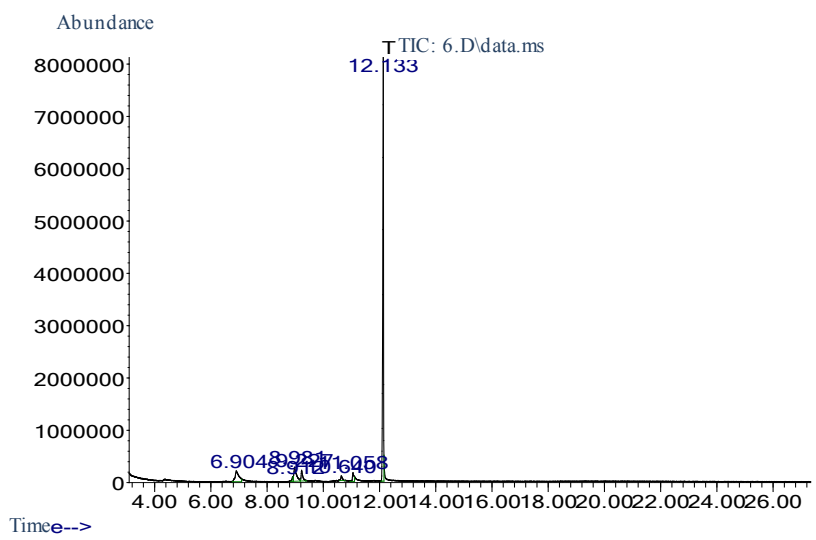

(e)

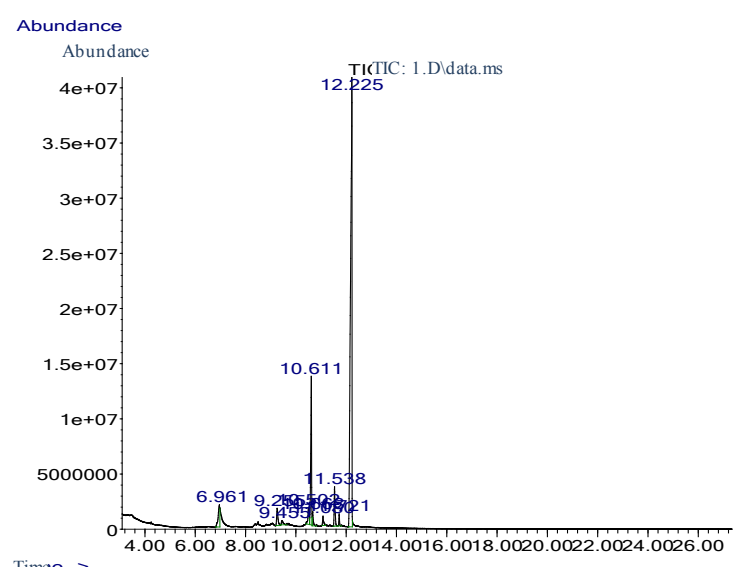

(b)

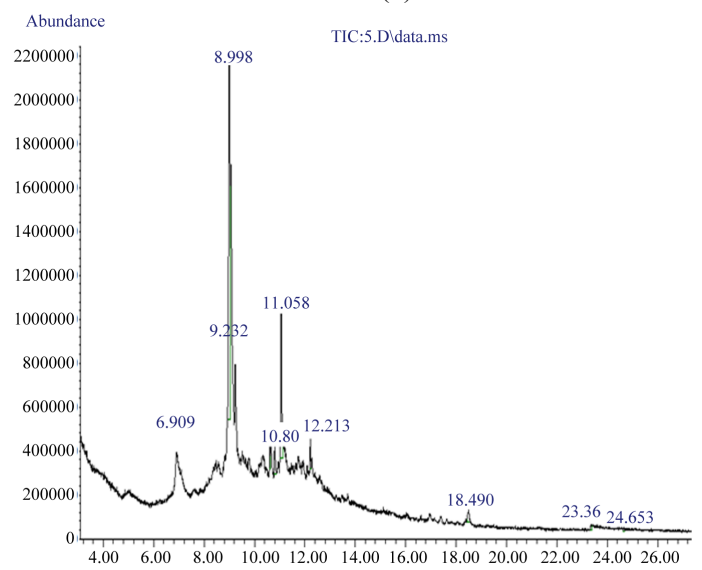

(d)

Abundance

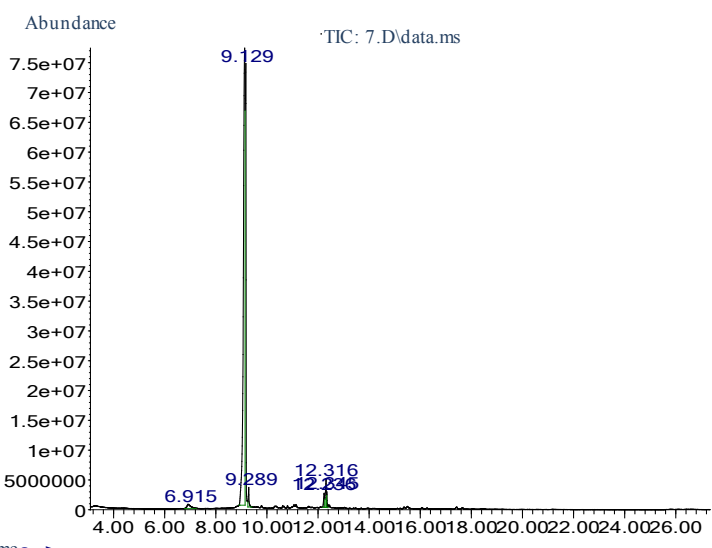

(f)

Figure 5. GC-MS chromatograms of products from catalytic cracking of camelina and canola oils at $500^{\circ} \mathrm{C}$ : (a) $\mathrm{UCMO}^{*}$; (b) CMMH; (c) CMDR; (d) UCNO; (e) CNMH; (f) CNDR. "UCMO: upgraded camelina oils; CMMH: camelina mixed hydrocarbons; CMDR: camelina distillation residues; UCNO: upgraded canola oils; CNMH: canola mixed hydrocarbons; CNDR: canola distillation residues.

Camelina oils produced at three different frequencies all contain 9,12,15-Octadecatrienoic acid, (Z,Z,Z)-, which is the main component. All canola oils produced at the three different frequencies also contain the same main component, oleic acid. However, other minor compositions in camelina oils and canola oils produced at 


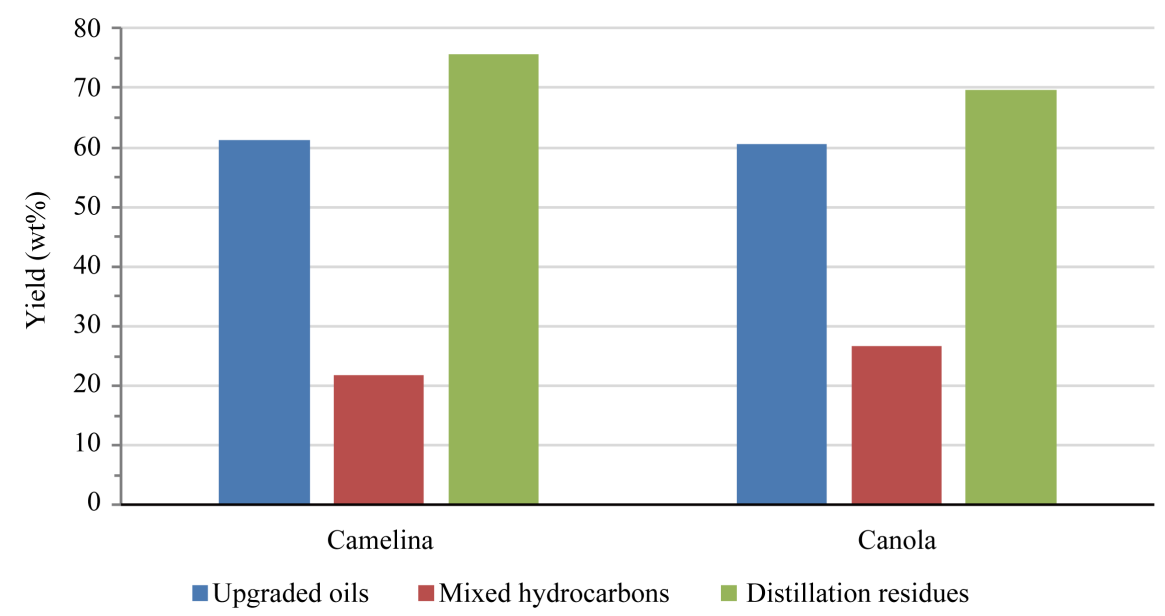

Figure 6. The yields of UCMO, CMMH, CMDR, UCNO, CNMH and CNDR.
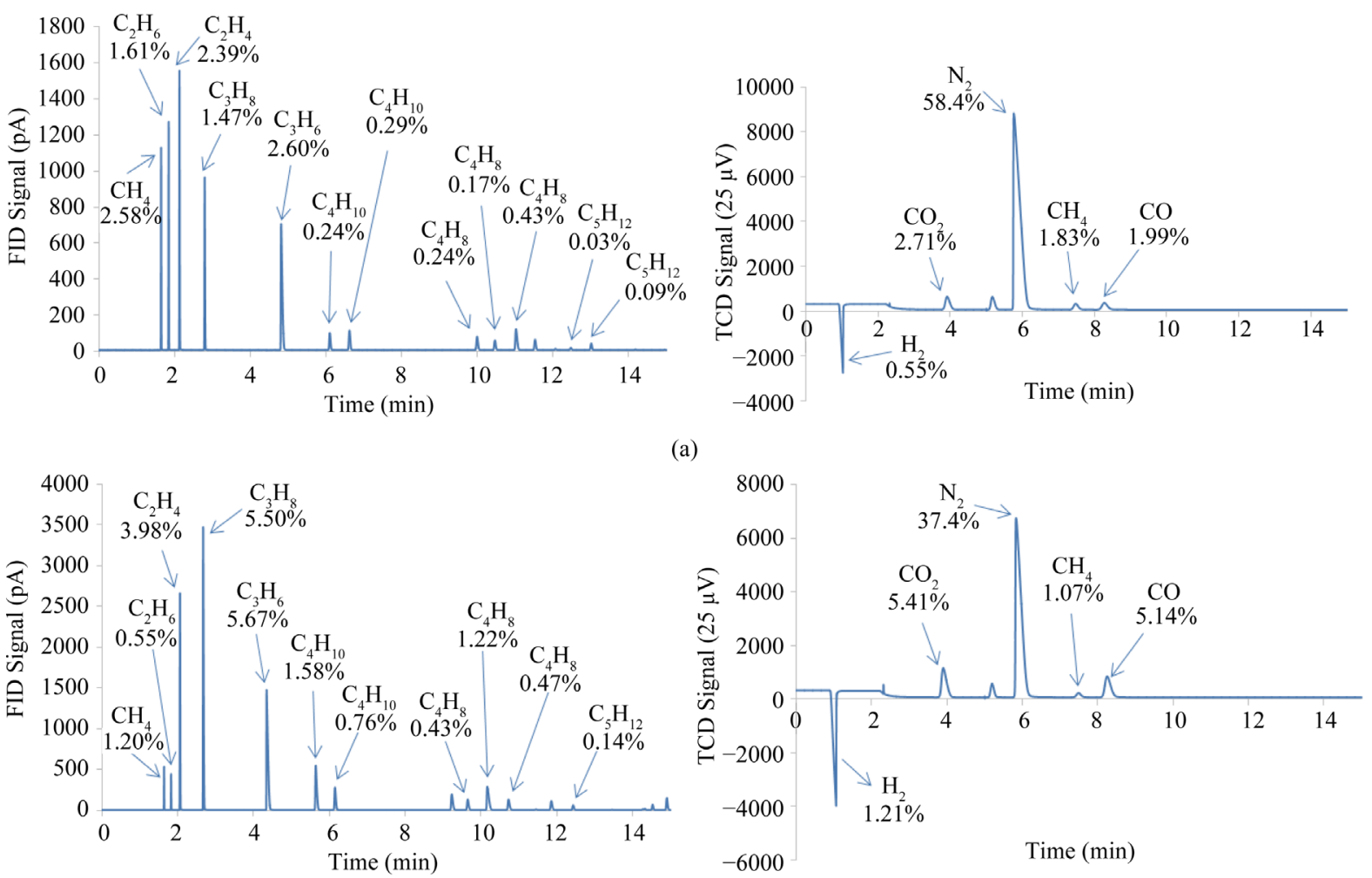

Figure 7. A typical GC analysis for non-condensable gases produced at $500^{\circ} \mathrm{C}$ from catalytic cracking of (a) camelina oils and (b) canola oils.

the three different frequencies are different.

The undesired properties of camelina and canola oils are improved after the catalytic cracking to some extent. After catalytic cracking, the density and viscosity of upgraded oils decrease, and the heating value increases. After the distillation treatment, the densities and viscosities of mixed hydrocarbons decrease further. The mixed hydrocarbons, which have met the moisture and viscosity requirements of bio-jet fuel, have the potential for future bio-jet fuel production. However, more work needs to be done for the effective upgrading of non-edible vegetable oils for future bio-jet fuel production. For example, several important parameters, such as catalyst activity, reaction temperature and liquid hourly space velocity during the catalytic cracking of vegetable oils, could be considered. In addition, recycling catalysts that have been used during the oil upgrading could reduce the 
processing cost of converting vegetable oils to bio-jet fuels.

\section{Acknowledgements}

This study was funded by the U.S. Department of Transportation through NC Sun Grant Initiative under Grant No. SA0700149. The authors would like to thank the Chemical Analytic Lab in the Chemistry Department of South Dakota State University for the GC-MS analysis of the oil samples. All the support is gratefully acknowledged. However, only the authors are responsible for the opinions expressed in this paper and for any possible error.

\section{References}

[1] Miraculas, G.A., Bose, N. and Raj, R.E. (2014) Optimization of Process Parameters for Biodiesel Extraction from Tamanu Oil Using Design of Experiments. Journal of Renewable and Sustainable Energy, 6, Article ID: 033120. http://dx.doi.org/10.1063/1.4880216

[2] Zhao, X., Wei, L. and Julson, J. (2014) First Stage of Bio-Jet Fuel Production: Non-Food Sunflower Oil Extraction Using Cold Press Method. AIMS Energy, 2, 193-209. http://dx.doi.org/10.3934/energy.2014.02.193

[3] Macrae, I., Oelke, E.A., Hutchison, W.D. and Nelson, J.J. (2000) Crop Profile for Canola in Minnesota. Minnesota Pesticide Impact Assessment Program (PIAP). http://www.ipmcenters.org/cropprofiles/docs/mncanola.pdf

[4] Ehrensing, D.T. and Guy, S.O. (2008) Camelina. Extension Service, Oregon State University, 1-7. http://extension.oregonstate.edu/gilliam/sites/default/files/Camelina em8953-e.pdf

[5] Maher, K.D. and Bressler, D.C. (2007) Pyrolysis of Triglyceride Materials for the Production of Renewable Fuels and Chemicals. Bioresource Technology, 98, 2351-2368. http://dx.doi.org/10.1016/j.biortech.2006.10.025

[6] Atabani, A.E., Silitonga, A.S., Ong, H.C., Mahlia, T.M.I., Masjuki, H.H., Badruddin, I.A. and Fayaz, H. (2013) NonEdible Vegetable Oils: A Critical Evaluation of Oil Extraction, Fatty Acid Compositions, Biodiesel Production, Characteristics, Engine Performance and Emissions Production. Renewable and Sustainable Energy Reviews, 18, 211-245. http://dx.doi.org/10.1016/j.rser.2012.10.013

[7] Cheng, J., Li, T., Huang, R., Zhou, J. and Cen, K. (2014) Optimizing Catalysis Conditions to Decrease Aromatic Hydrocarbons and Increase Alkanes for Improving Jet Biofuel quality. Bioresource Technology, 158, 378-382. http://dx.doi.org/10.1016/j.biortech.2014.02.112

[8] Demirbas, A. (2003) Fuel Conversional Aspects of Palm Oil and Sunflower Oil. Energy Sources, 25, 457-466. http://dx.doi.org/10.1080/00908310390142451

[9] Ma, Z., Wei, L., Qu, W., Julson, J., Zhu, Q. and Wang, X. (2013) The Effect of Support on the Catalytic Performance for Bio-Oil Upgrading. Advanced Materials Research, 608-609, 350-355. http://dx.doi.org/10.4028/www.scientific.net/AMR.608-609.350

[10] Yetim, H., Sagdic, O. and Ozturk, I. (2008) Fatty Acid Compositions of Cold Press Oils of Seven Edible Plant Seeds Grown in Turkey. Chemistry of Natural Compounds, 44, 634-636. http://dx.doi.org/10.1007/s10600-008-9131-y

[11] Mohanty, A.K., Tummala, P., Liu, W., Misra, M., Mulukutla, P.V. and Drzal, L.T. (2005) Injection-Molded Biocomposites from Soy Protein Based Bioplastic and Short Industrial Hemp Fiber. Journal of Polymers and Environment, 13, 279-285. http://dx.doi.org/10.1007/s10924-005-4762-6

[12] Berot, S., Compoint, J.P., Larre, C., Malabat, C. and Gueguen, J. (2005) Large-Scale Purification of Rapeseed Proteins (Brassica napus L.). Journal of Chromatography B, 818, 35-42. http://dx.doi.org/10.1016/j.jchromb.2004.08.001

[13] Demirbas, A.H. and Demirbas, I. (2007) Importance of Rural Bioenergy for Developing Countries. Energy Conversion and Management, 48, 2386-2398. http://dx.doi.org/10.1016/j.enconman.2007.03.005

[14] Rombaut, N., Savoire, R., Thomasset, B., Belliard, T., Castello, J., Hecke, E.V. and Lanoiselle, J. (2014) Grape Seed Oil Extraction: Interest of Supercritical Fluid Extraction and Gas-assisted Mechanical Extraction for Enhancing Polyphenol Co-Extraction in Oil. Comptes Rendus Chimie, 17, 284-292. http://dx.doi.org/10.1016/j.crci.2013.11.014

[15] Biswas, S., Biswas P. and Kumar, A. (2012) Catalytic Cracking of Soybean Oil with Zirconium Complex Chemically Bonded to Alumina Support without Hydrogen. International Journal of Chemical Sciences and Applications, 3, 306313.

[16] Chin, H.F., Krishnapillay, B. and Stanwood, P.C. (1989) Seed Moisture: Recalcitrant vs. Orthodox Seeds. Seed Moisture, 14, 15-22.

[17] Lam, P.S., Sokhansanj, S., Bi, X., Lim, C.J., Naimi, L.J., Hoque, M., Mani, S., Womac, A.R., Ye, X.P. and Narayan, S. (2008) Bulk Density of Wet and Dry Wheat Straw and Switchgrass Particles. Applied Engineering in Agriculture, 24, 351-358. http://dx.doi.org/10.13031/2013.24490 
[18] Chen, Y., Wang, C., Lu, W. and Yang, Z. (2010) Study of the Co-Deoxy-Liquefaction of Biomass and Vegetable Oil for Hydrocarbon Oil Production. Bioresource Technology, 101, 4600-4607. http://dx.doi.org/10.1016/j.biortech.2010.01.071

[19] Rodenbush, C.M., Hsieh, F.H. and Viswanath, D.S. (1999) Density and Viscosity of Vegetable Oils. Journal of the American Oil Chemists' Society, 76, 1415-1419. http://dx.doi.org/10.1007/s11746-999-0177-1

[20] Jimenez, J.J., Bernal, J.L., del-Nozal, M.A., Martin, M.A. and Bernal, J. (2006) Sample Preparation Methods for Beeswax Characterization by Gas Chromatography with Flame Ionization Detection. Journal of Chromatography A, 1129, 262-272. http://dx.doi.org/10.1016/j.chroma.2006.06.098

[21] Hamerton, I., Emsley, A.M., Hay, J.N., Herman, H., Howlin, B.J. and Jepson, P. (2006) The Development of Controllable Complex Curing Agents for Epoxy Resins Part 3. An Investigation of the Shelf Life and Thermal Dissociation Behavior of Bis(acetanilido)-tris(acetato)dicuprate(II). Journal of Materials Chemistry, 16, 255-265. http://dx.doi.org/10.1039/b510393b

[22] Requena, J.F., Guimaraes, A.C., Alpera, S.Q., Gangas, E.R., Navarro, S.H., Gracia, L.M., Gil, J.M. and Cuesta, H.F. (2011) Life Cycle Assessment (LCA) of the Biofuel Production Process from Sunflower Oil, Rapeseed Oil and Soybean Oil. Fuel Processing Technology, 92, 190-199. http://dx.doi.org/10.1016/j.fuproc.2010.03.004

[23] Peterson, J., Carlson, R., Richter, B. and Knowles, D. (2009) Extraction of Oil from Oilseeds Using Accelerated Solvent Extraction (ASE). LCGC.

[24] Laaniste, P., Joudu, J. and Eremeev, V. (2004) Oil Content of Spring Oilseed Rape Seeds According to Fertilisation. Agronomy Research, 2, 83-86.

[25] Bezergianni, S., Voutetakis, S. and Kalogianni, A. (2009) Catalytic Hydrocracking of Fresh and Used Cooking Oil. Industrial \& Engineering Chemistry Research, 48, 8402-8406. http://dx.doi.org/10.1021/ie900445m

[26] Santillan-Jimenez, E., Morgan, T., Lacny, J., Mohapantra, S. and Crocker, M. (2013) Catalytic Deoxygenation of Triglycerides and Fatty Acids to Hydrocarbons over Carbon-supported Nickel. Fuel, 103, 1010-1017. http://dx.doi.org/10.1016/j.fuel.2012.08.035

[27] Rustan, A.C. and Drevon, C.A. (2005) Fatty Acids: Structures and Properties. Encyclopedia of Life Sciences, 1-7.

[28] Yaliwal, V.S., Daboji, S.R., Banapurmath, N.R. and Tewari, P.G. (2010) Production and Utilization of Renewable Liquid Fuel in a Single Cylinder for Stroke Direct Injection Compression Ignition Engine. International Journal of Engineering Science and Technology, 2, 5938-5948.

[29] Jet A/Jet A-1 (1999) Environment Canada, Emergencies Science and Technology Division (Bulletin, Data from Shell). http://www.etc-cte.ec.gc.ca/databases/Oilproperties/pdf/WEB_Jet_A-Jet_A-1.pdf

[30] Qu, W., Wei, L. and Julson, J. (2013) An Exploration of Improving the Properties of Heavy Bio-Oil. Energy \& Fuels, 27, 4717-4722. http://dx.doi.org/10.1021/ef400418p

[31] Fadock, M.N. (2010) Carbon Profile Matching, Algae Fatty Acids and Jet A Fuel Properties. Guelph Engineering Journal, 3, 1-8.

[32] Li, Y., Shao, J., Wang, X., Yang, H., Chen, Y., Deng, Y., Zhang, S. and Chen, H. (2013) Upgrading of Bio-Oil: Removal of the Fermentation Inhibitor (Furfural) from the Model Compounds of Bio-Oil Using Pyrolytic Char. Energy \& Fuels, 27, 5975-5981. http://dx.doi.org/10.1021/ef401375q

[33] Zhang, J., Toghiani, H., Mohan, D., Pittman Jr., C.U. and Toghiani, R.K. (2007) Product Analysis and Thermodynamic Simulations from the Pyrolysis of Several Biomass Feedstocks. Energy \& Fuels, 21, 2373-2385. http://dx.doi.org/10.1021/ef0606557

[34] Ofori-Boateng, C., KeatTeong, L. and JitKang, L. (2012) Comparative Exergy Analyses of Jatropha curcas Oil Extraction Methods: Solvent and Mechanical Extraction Processes. Energy Conversion and Management, 55, 164-171. http://dx.doi.org/10.1016/j.enconman.2011.11.005

[35] Zhang, H., Cheng, Y., Vispute, T.P., Xiao, R. and Huber, G.W. (2011) Catalytic Conversion of Biomass-Derived Feedstocks into Olefins and Aromatics with ZSM-5: The Hydrogen to Carbon Effective Ratio. Energy \& Environmental Science, 4, 2297-2307. http://dx.doi.org/10.1039/clee01230d 
Scientific Research Publishing (SCIRP) is one of the largest Open Access journal publishers. It is currently publishing more than 200 open access, online, peer-reviewed journals covering a wide range of academic disciplines. SCIRP serves the worldwide academic communities and contributes to the progress and application of science with its publication.

Other selected journals from SCIRP are listed as below. Submit your manuscript to us via either submit@scirp.org or Online Submission Portal.
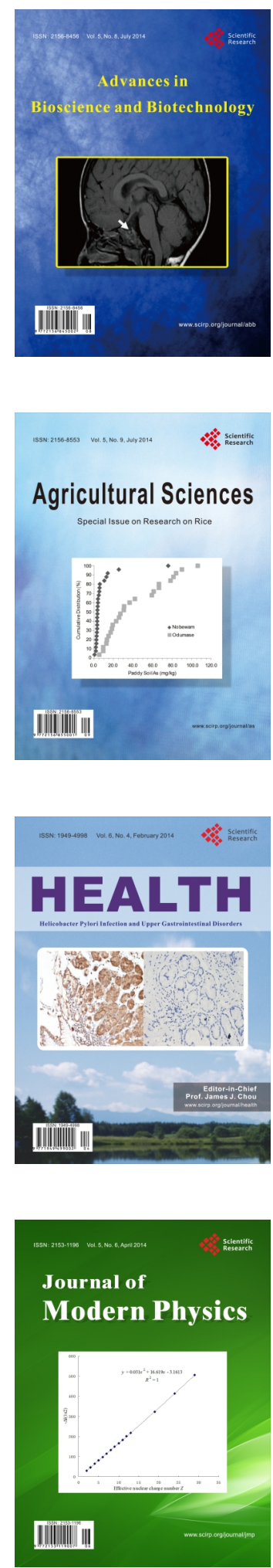
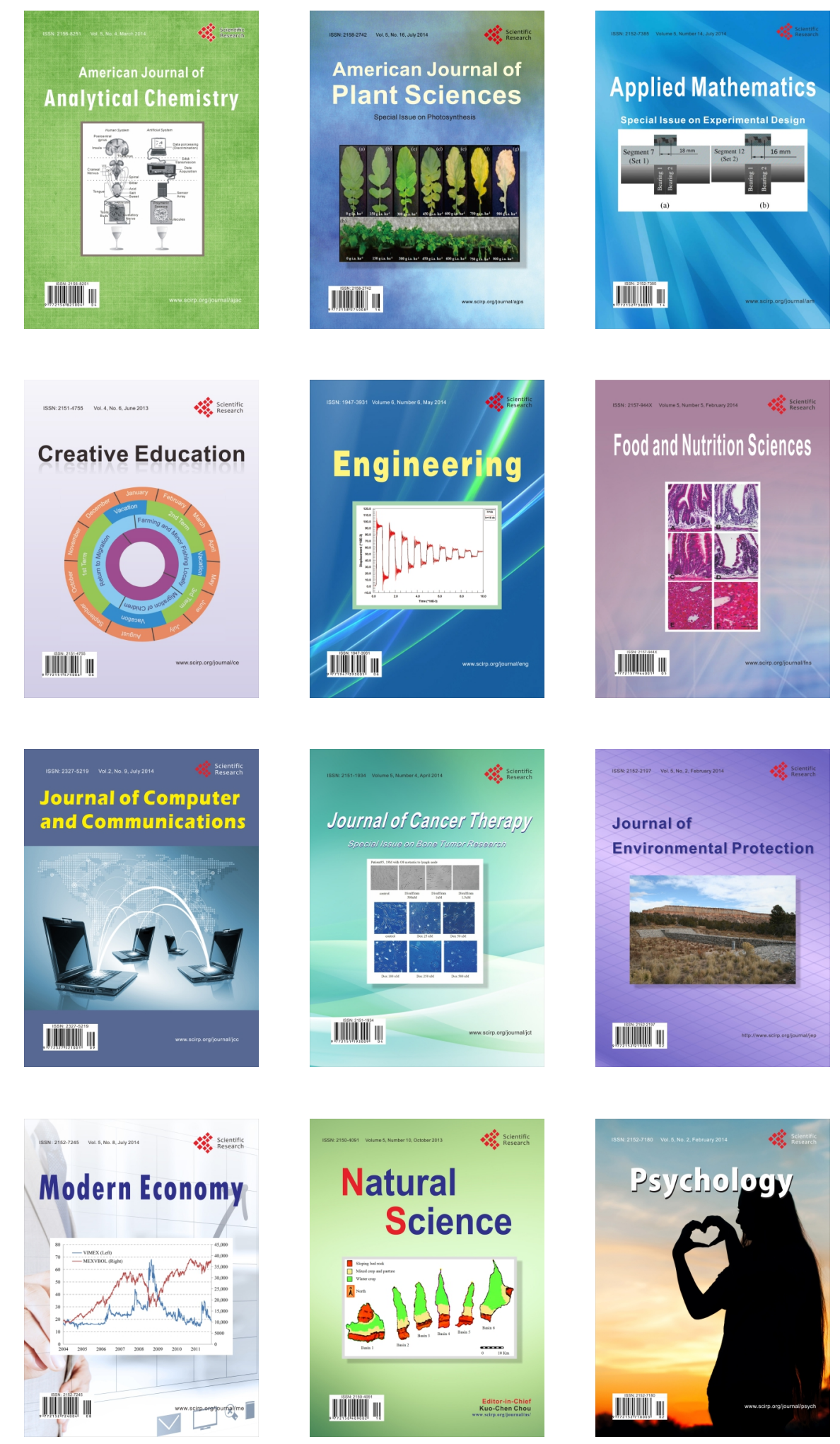